\title{
Study No. 14, July 2013 \\ When Opportunity Beckons: The Impact of the Public Service Accountability Monitor's Work on Improving Health Budgets in South Africa ${ }^{1}$
}

Alta Fölscher ${ }^{2}$ and John Kruger $^{3}$

\section{Introduction}

The health sector program of the Public Sector Accountability Monitor (PSAM) in Grahamstown, South Africa, monitors the public resource management cycle and selected service delivery issues in the country's Eastern Cape Province. The health sector program forms part of PSAM's monitoring and advocacy work, which is aimed at improving the quality of budget processes by monitoring the budget cycle, producing a series of routine reports mapped to the cycle, and undertaking ad hoc and responsive research and advocacy interventions. PSAM's health program is based on the proposition that weak public resource management processes and capacity in the province - and particularly in the health sector - have resulted in weak accountability and have had a "direct and detrimental impact upon the effective use of public funds and the delivery of social services to the citizens of this province."

This report on the impact of PSAM's health program is the final output of a three-year case study. The report looks at the period from 2007 to 2012, documenting activities and impacts in the health sector since the emergence of PSAM's monitoring and advocacy program. It presents a cumulative assessment of the impact of the activities of the program against its own theory of change, as posed at the start of the research and amended over the period. The key question asked in the report is whether PSAM has contributed through its activities to improvements in public resource management in the Eastern Cape Department of Health $(\mathrm{ECDoH})$, and if so, on account of which internal and external factors.

The potential of PSAM's health program to contribute to change in the sector was affected by a series of events during the course of the study. Beginning in 2010 PSAM was reoriented and restructured. In January 2011 PSAM's most experienced researcher departed, and four months later PSAM's leadership was replaced.

\footnotetext{
${ }^{1}$ This case study focuses on the public health sector research and advocacy work of the Public Sector Accountability Monitor (PSAM), an affiliated institution of Rhodes University, in Grahamstown, Eastern Cape Province, South Africa. Over a period of three years, the study tracked whether and how PSAM achieved its objectives in the health sector through the implementation of its advocacy strategies. The case study draws on primary research (interviews in 2010, 2011, and 2012); on primary documentation, such as government budgets, annual reports, and other reports; as well as on secondary sources, including published reports, papers, and articles.

2 Alta Fölscher is a researcher and consultant who undertakes work in the areas of expenditure and public financial management; public governance and transparency; and aid management and evaluation. She has worked extensively in South Africa, but also elsewhere in Africa; the Middle East; Eastern Europe; Central, South, and East Asia; and the Caribbean. She holds an MSc in Public Policy and Management from the University of London, and post graduate degrees in Political Science, and Business Administration and Journalism from the Universities of Cape Town and Stellenbosch, respectively.

${ }^{3}$ John Kruger is a development economist and researcher with over 10 years public administration experience at a senior level in the South African government (National Treasury and Department of Education). Before joining government, he lectured and trained on economics, social policy, and budgeting. His recent consulting work has focussed on education, health and social protection policy and financing, and in the areas of public finance and budgeting. He holds a Master's degree in economics from the University of Stellenbosch.

${ }^{4}$ J. Kruuse and D. Luyt, "Taking the Auditor General more seriously," Centre for Social Accountability Press Release, 2007.
} 
The fieldwork, however, has shown limited impact of this interruption on perceptions of PSAM among the organization's strategic partners and advocacy targets, despite few outputs from early 2011 to mid-2012.

Despite these internal organizational challenges, and a difficult political environment within which to effect change, the case study is able to describe linkages between PSAM's work and efforts during the second period of the case study to clean up the financial management of the Health Department and to introduce critical reforms. At the same time, however, it also describes how these reforms are frustrated by persistent barriers to change.

The report sets out the case study results in five main sections followed by a conclusion.

- Health challenges in the Eastern Cape

- PSAM's strategy to improve health services

- Changes observed at the Department of Health

- Understanding the contribution of PSAM's campaign

- Alternative explanations of change

\section{The Issues: Health Challenges in the Eastern Cape}

The public health research and advocacy program of PSAM monitors public resource management and service delivery issues in South Africa's Eastern Cape Province. Its work aims to strengthen the dialogue between citizens and the state during the budget cycle — and ultimately to improve health service delivery, such as HIV/AIDS care and emergency medical services.

During the case study period, PSAM's health program responded to frequent service delivery failures and a long history of weak public resource management in the health sector in the province. This, however, is neither unique to the health sector, nor to other sectors in the province. Service delivery and public resource management challenges are experienced throughout the province, and throughout the country's health sector.

\section{The provincial context}

In terms of per capital income, the Eastern Cape is South Africa's second poorest province - the regional or second tier of government. In 200863.5 percent of the population fell below a poverty line of R 502 (\$US 52) per month. Only Limpopo Province has a higher percentage, at 63.8 percent. The national percentage is 47 percent. ${ }^{5}$ At the same time, almost a fifth of the national population with an income below this poverty line lived in the Eastern Cape. It is also the province most in need of infrastructure, such as clean water and sanitation, and of improvement in life circumstances, such as employment and family planning. ${ }^{6}$ In $2006-07$ only 16 percent of the rural population between the ages of 15 and 64 were employed. That is, 84 percent of this population is either unemployed or "not economically active."

The Eastern Cape was established as one of nine provinces after the country's first democratic elections in 1994. The new province incorporated the former homelands of the Transkei and Ciskei, which had been provided with inadequate resources in terms of public infrastructure and service delivery for decades. ${ }^{8}$

At inception, the new province faced a triple apartheid legacy: high incidence of poverty and unemployment, poor public infrastructure, and poor human resource capacity. ${ }^{9}$ The province's immediate capacity to gear

${ }^{5}$ J. Argent, A. Finn, et al. "National Income Dynamics Study: Poverty: Analysis of the NIDS Wave 1 Dataset," SALDRU, University of Cape Town, 2009.

${ }^{6}$ StatsSA, "Measuring Poverty in South Africa," Statistics South Africa, Pretoria, 2002.

7 A. Westaway, "Rural poverty in South Africa: Legacy of apartheid or consequence of contemporary segregationism?" in Overcoming Poverty and Structural Inequality in South Africa (PLAAS, Johannesburg, South Africa), 2010, p. 3.

${ }^{8}$ Human Sciences Research Council, "Service Need and Provision in the Eastern Cape. Pretoria," 1998. 
public service delivery to address these issues was impaired by the complexity of merging parts of the Cape Provincial administration with the Ciskei and Transkei administrations. This process - of which the effects are still evident today — encountered disparate public systems, legal frameworks, and processes; a combined staff complement with differing remuneration grades and salary scales; and both over- and under-staffing in various parts of the administration. ${ }^{10}$

At the same time, the environment within which the new administration had to establish itself was not stable. Like all provinces the Eastern Cape had to deal with continuous reform over the next decade in respect of its budget and public financial management, including the introduction of a new intergovernmental fiscal system; a medium-term expenditure framework approach; new financial management legislation, regulations, and frameworks; new budget classifications and chart of accounts; new strategic planning and annual planning formats; and new performance budgeting, monitoring, and evaluation approaches. While these changes, in principle, should have resulted in improved budget management, in practice they resulted in reduced stability and space for the implementation of reforms.

The Eastern Cape has a strong anti-apartheid struggle legacy and is the birthplace of two of South Africa's post-apartheid Presidents, Nelson Mandela and Thabo Mbeki. It has long been a stronghold of the ruling African National Congress (ANC) and contributes the second largest number of delegates to the ANC elective congress, a key battlefield in South African politics (given the electoral dominance of the party, the congress effectively elects the country's President). At the time of the study's baseline (2007), the party's dominant position in the province seemed to have strengthened, with 79.3 percent of the votes cast at the provincial level in 2004, compared to 73.8 percent in 1999. The 2006 municipal elections also showed high support for the ANC, with 81.6 percent of the votes cast across municipalities, up from 75.8 percent in the 2000 elections. The province was governed by Premier Nosimo Balindlela, who was an ally of then-President Thabo Mbeki.

Politics and business are closely linked in South Africa, with pressure after the 1994 elections to transfer political and economic power to the majority black population from the minority white population. Whereas the political power has shifted, economic power remains in the hands of the whites, and the main route to black economic power is perceived to be through state spending. ${ }^{11}$ As one prominent political scientist commented, "In post-apartheid South Africa, patronage is facilitated through both the State and capital. The change in the relationship between the ANC and State power after 1994 has resulted in a confluence of political and business interests. This, in turn, has created a circular relationship between politics and money. In other words, access to political power facilitates access to money, and access to money can buy political influence." 12 While entry to politics offers a smaller group of politicians access to power and resources within the economy, state employment and state tenders - with emphasis on affirmative action and black economic empowerment, respectively — extend this to a larger group of individuals. To a great extent, however, the majority of blacks are still trapped in poverty, with perceptions on the rise that the state has been captured by the interests of its office holders and officials. ${ }^{13}$

These linkages between politics and business are nowhere seen to be more prominent than in the Eastern Cape. For example, in the early 2000s over 63 percent of respondents perceived "most" or "all" of civil

\footnotetext{
${ }^{9}$ S. Cwati, "Comparing Anti-corruption Strategies in South Africa's Western and Eastern Cape Provinces," School of Government, University of the Western Cape MPA, Cape Town, 2004, p. 31.

10 Ibid, p. 38, citing Allan, Mattes and Mille, 2002.

11 M. Mbeki, “ANC elite hoodwinking the poor," SAPA Times Live, 25 May 2012, available at: http://www.timeslive.co.za/politics/2012/05/25/anc-elite-hoodwinking-poor---moeletsi-mbeki.

12 A. Matshiqi, "Politics and Money, A Circular Relationship," Engineering News, 6 October 2009.

13 The Reconciliation Barometer, an annual survey conducted on citizens' attitudes to political and socioeconomic transformation, has shown a steady drop in citizens' confidence in national, provincial, and local state institutions between 2006 and 2009. After an uptick in 2010, associated with the country's successful hosting of the Soccer World Cup, confidence again deteriorated in 2011 (K. LefkoEverett, "SA Reconciliation Barometer Survey, 2012 Report," Institute for Justice and Reconciliation, Cape Town, 2012).
} 
servants in the Eastern Cape to be involved in corruption. ${ }^{14}$ The administration itself admitted to the rising challenge posed by corruption and put in place various measures to deal with it, none of which have been fully effective. An anti-corruption council (established by the Premier and comprising mostly state agencies) and network against corruption (established by the Speaker of the Provincial Legislature and including civil society groups, including PSAM) met with frustration in the 2000s on account of poor support, low capacity, and the poor handling of an anti-corruption case (against the head of the Department of Health) reported by the network. In response to the criticism, the provincial Premier accused the legislature of partisan bias, saying lawmakers were co-opted by interests that wanted to embarrass the province and Premier. ${ }^{15}$ These bodies are still in existence, although the network was discontinued in 2005-06 and replaced by the Provincial Anti-Corruption Forum. The latter is characterized by poor attendance by government delegates, particularly heads of departments.

By 2008 a number of national and provincial government interventions appeared in the province that aimed to improve financial management and increase levels of public service delivery. As far back as 1996 thenPresident Nelson Mandela created the Special Investigation Unit to address mismanagement in the province. Between 1998 and 2000 the national cabinet invoked Section 100 of the Constitution, enabling it to assume direct control over failing provincial government departments. When this intervention failed to improve the state of financial management, the national cabinet intervened again in 2003, when it dispatched an Interim Management Team (IMT) to assume direct management of over 80 percent of the Eastern Cape budget. In tandem with this initiative, a Joint Anti-Corruption Task Team (JACTT) was dispatched to investigate and prosecute a backlog of corruption and fraud cases involving the provincial administration. On 8 April 2005 then-Eastern Cape Premier Nosimo Balindlela announced the establishment of a Judicial Commission of Inquiry into the Finances of the Eastern Cape. The work of the commission, however, came to nothing. The Premier, after being removed from office by new President, Jacob Zuma, was accused by rival factions in the province of having used the commission to discredit her political foes. The High Court later prevented the publication of the report on a legal technicality.

By 2007 the Eastern Cape Province was still struggling with the combined effects of high demand for public services, poor capacity, endemic corruption, and dysfunctional systems. These challenges to regular and accountable management of public resources in the Eastern Cape were also highlighted in the consolidated audit report for the Eastern Cape provincial government for 2007-08. ${ }^{16}$ Common shortcomings identified were noncompliance with relevant legislation and weak internal controls related to inadequate governance arrangements; insufficient leadership, supervision and monitoring; and weak capacity. ${ }^{17}$ A report on the senior managers in the province for 2006-07 found that only 49 percent had valid performance agreements in place, a statutory requirement for senior management. The $\mathrm{ECDoH}$ was the worst performing department, with only 35 percent of agreements submitted, and also the highest number of senior service positions in the province. ${ }^{18}$

Not a single department in the Government of the Eastern Cape had an unqualified audit for 2007-08: of the 13 departments audited, seven received a qualified financial audit and two, an adverse opinion, one of which was the ECDoH. The remaining six were unqualified financially, but had concerns in areas of internal control, governance, and legislative noncompliance.

\footnotetext{
${ }^{14}$ Cwati, p. 37.

${ }^{15}$ Cwati, 2004.

16 Auditor General of South Africa, "General Report of the National Audit Outcomes of the Eastern Cape, Fiscal Year 2007/8,"

Pretoria, 2008.

17 Ibid, p. 2.

18 Public Service Commission, "Report on Senior Management Service Compliance with Performance Agreements in the Eastern

Cape Provincial Administration,” Pretoria, 2007.
} 


\section{The health sector in the Eastern Cape}

These challenges also were manifested in the health sector resource management and outcomes, making the Eastern Cape the worst performing province in South Africa with respect of health outcomes. This in a country in which overall health outcomes lag countries with similar incomes (see Box 1).

\section{Box 1. Health Outcomes in South Africa}

Although a middle-income country, South African health outcomes are similar to countries with much lower income levels. In addition, key health outcomes have been worsening. South Africa is one of only 12 countries in the world where mortality rates for children younger than five years have increased since 1990. ${ }^{1}$ South Africa also lags countries in terms of human development with a comparable per capita income. In terms of life expectancy, it even lags countries with much lower per capita income and HDI rankings. Life expectancy in South Africa is below that in Kenya and Tanzania, although those countries have per capita incomes that are only 12 to 13 percent of South Africa's.

${ }^{1}$ H. Coovadia, R. Jewkes, et al., "Health in South Africa 1: The Health and Health System of South Africa: Historical Roots of Current Public Health Challenges," Lancet 374, 2009, pp. 817-34.

These weak and worsening health outcomes relate to the "quadruple burden of disease" facing the country, described as the simultaneous occurrence in South Africa of high levels of infectious diseases (normally associated with poor countries), relatively high levels of chronic disease (more common to high-income countries), a high incidence of injury related health needs, and HIV/AIDS. ${ }^{19}$

These outcomes, however, also relate to problems with access to and quality of service delivery: “...failures in leadership and stewardship and weak management have led to inadequate implementation of what are often good policies. Pivotal facets of primary health care are not in place and there is a substantial human resources crisis facing the health sector." 20 With regard to hospital services one commentator remarked that "public hospitals in South Africa are dysfunctional and suffer from high degrees of institutional stress" and that "the result was poor clinical outcomes and higher levels of morbidity and mortality than ought to be the case." 21

Health outcomes confirm the Eastern Cape's relative socioeconomic status compared to other provinces. In a 2008 overview of the status of South Africa with regard to health Millennium Development Goals (MDGs), the Eastern Cape rated last of the nine provinces with regard to five key indicators. ${ }^{22}$ Its service delivery indicators and health inputs also lagged other provinces (see Annex 2 for tables).

\section{Health resource management in the Eastern Cape}

In this case study's baseline year of 2007, the ECDoH faced a number of key challenges with respect to the quality of public resource management. Many of these were highlighted in PSAM documentation at the time, including poor financial management, a lack of accountability on the part of administrators and managers and recurring high instance of fruitless and wasteful expenditure. ${ }^{23}$

\footnotetext{
${ }^{19}$ D. Bradshaw, N. Nannan, et al., "South African National Burden of Disease Study 2000 Eastern Cape Province," South African National Burden of Disease Study 2000, Medical Research Council, Cape Town, n.d.

${ }^{20}$ H. Coovadia, R. Jewkes, et al., "Health in South Africa 1: The Health and Health System of South Africa: Historical Roots of Current Public Health Challenges," Lancet 374, 2009, pp. 817-34.

${ }^{21}$ K. Von Holdt, "Can a Weak State be a Developmental State? Questions Arising from Institutional Weaknesses in the South African State" presentation at conference on The Potentials for and Challenges of Constructing a Democratic Developmental State in South Africa, Human Services Research Council \& DBSA, Magaliesberg, South Africa, 2008.

22 C. Day and A. Gray, "Chapter 16: Health and Related Indicators," in P. Barron and J. Roma-Rearden, South African Health Review 2008, Health Systems Trust, Durban, 2008.

${ }^{23}$ D. Eagar, "Budget Analysis, Eastern Cape Department of Health, 2008/9," Centre for Social Accountability, 2008.
} 
In budgeting, PSAM reports from the time note a disconnection between policy commitments and allocations. Several areas that had been highlighted as policy commitments, such as emergency services and tuberculosis treatment, had actually seen funding cuts. One expenditure tracking report showed underspending on capital allocations (including a 98 percent underspending on the purchase of machinery and equipment), combined with overspending on the recurrent budget, particularly remuneration costs. ${ }^{24}$

Planning protocols in the department were also weak. ${ }^{25}$ An assessment of the department's strategic plan pointed out poor coverage of revenue streams; inconsistencies between long-term, medium-term and shortterm plans; vague objectives and weak performance indicators; poor costing; weak indication of responsibilities and vague commitments in terms of improving compliance with the legal framework for PFM (public finance management), among other issues.

These findings were also reflected in Auditor General's reports for the ECDoH. By 2007 the ECDoH had a 10-year history of adverse and qualified audits. The 2007-08 audit opinion was again adverse, based on inadequate reconciliations, insufficient controls and monitoring, together with the lack of supporting documentation. The Auditor General noted in his report that during the audit there was a lack of documentation and senior managers were not available. Furthermore, the department had not implemented the previous year's substantial audit recommendations. ${ }^{26}$

Jaffray and Miti, who did a survey on the conditions in the public health sector in the Eastern Cape, noted key management issues that had led to poor service delivery. ${ }^{27}$ These included human resource issues (which PSAM observed had not been addressed in strategic plans) and weak leadership.

In conclusion, in 2007 the ECDoH, the target institution for PSAM's health research and advocacy program, was one of the worst performing departments in terms of service delivery and financial performance in an underperforming province that was perceived to be corrupt, and which had been the subject of several interventions by national government — all with little success.

\section{The Campaign: PSAM's Strategy to Improve Health Services \\ PSAM's Theory of Change}

Elements of PSAM's theory of change for its health program changed during the case study as the organization learned from its first years of implementation and adapted to the changing environment. This section, therefore, details the original theory of the change and discusses key changes.

$\underline{2007 \text { to } 2010}$

In the case study's baseline year of 2007, PSAM was subsumed by the newly created Centre for Social Accountability, which had as its core mission the "institutionalization of the right to social accountability and the realization of social and economic rights and capabilities through the effective management of public resources." 28

For PSAM, 2007 marked a departure from a more confrontational strategy of engagement with government to a more cooperative strategy. Prior to 2007-08 PSAM's strategy was to "shame and blame." Its main tool was to track corruption cases through a province-wide database and draw attention to the provincial

${ }^{24}$ D. Eagar, "Expenditure Tracking Report, Eastern Cape Department of Health, 2007/8," Centre for Social Accountability, 2008.

${ }^{25}$ D. Eagar, "Strategic Plan Evaluation, Eastern Cape Department of Health, 2008/9," Centre for Social Accountability, 2008.

${ }^{26}$ Auditor General of South Africa, 2008.

27 P. Jaffray and L. Miti, "Primary Health Care Service Delivery," No. 7 in the Eastern Cape Basic Services Delivery and Socio Economic Trends Series, FHISER, University of Fort Hare, 2010.

28 PSAM, "Centre for Social Accountability: Framework for Change," internal strategy document, 21 August 2008, p. 3. PSAM has since reverted to its original name. 
government's failure to successfully conclude many of these cases. The content of its reports and media releases was often personalized to individuals. As it shifted into more research-oriented work, PSAM instead began to publicize exposés of incompetence, maladministration, theft, fraud, and corruption. The organization, for example, exposed the poor quality of provincial health plans in an extensive opinion piece in a local newspaper.

After a strategic reorientation in 2007-08, however, PSAM began to take a more moderate approach, highlighting both government successes and failures. This strategy shift was expected to open more possibilities for PSAM to work with strategic partners and public officials directly, which was seen as a key part of the strategy for improving the organization's impact on public resource management, particularly in a context where formal and social accountability is weak. It was also feared that a narrow confrontational approach was counterproductive, as it allowed officials to dismiss reports as witch hunts and politically motivated.

In 2008 PSAM formulated the Framework of Change for the health program, which formalized the new mission and strategy. According to the Framework, PSAM would monitor the public resource management cycle, analyze its outputs and outcomes, and undertake advocacy based on this research. While it more explicitly related to the second part of the PSAM/CSA mission ("the realization of social and economic rights and capabilities through the effective management of public resources"), it also supported the first part ("institutionalization of the right to social accountability").

PSAM/CSA postulated that for any public administration to function effectively, individual managers and political leaders must ensure the production of rigorous and detailed planning and budget documents, as well as financial and performance reports. PSAM/CSA reasoned that the failure to produce these documents or to ensure their accuracy, rigor, and relevance, inevitably undermines the delivery of effective and responsive public services.

Furthermore, if civic actors and interest groups are to campaign for the effective management of public services and the realization of their socioeconomic rights, they need to obtain information on the resources available to public service providers and on the use of these resources. The availability of such information depends, however, on five social accountability processes within the state, namely: planning and resource allocation; expenditure management; performance management; and integrity and oversight. ${ }^{29}$

Initially PSAM/CSA focused on producing a series of five routine reports that track the public resource management cycle. These included:

1. a Provincial Budget Analysis and Strategic Plan Evaluation;

2. a research report providing detailed evaluations of service delivery problems;

3. a Service Delivery Review at the end of the financial year that contains an evaluation of expenditure, performance, and public integrity management, once the annual report and Auditor General's report have been tabled in the legislature; and

4. an Accountability to Oversight Report, produced after scrutiny by the legislature of the department's performance and tracking the implementation of the oversight process.

In the organization's original theory of change, the impact of these outputs was to be enhanced through the following tactics:

1. Disseminating outputs to key advocacy targets: such as heads of government departments, members of the parliamentary committees, civil society organizations, research institutions, and the media, followed by targeted briefings. The general dissemination of its formal outputs is backed by responsive engagement with provincial and national media on issues of the day.

${ }^{29}$ PSAM, 2008. 
2. Engaging civil society partners: After the review of its strategy in 2008, PSAM/CSA sought to actively encourage partner civic interest groups to participate, formally and informally, in a more inclusive advocacy strategy around its outputs.

3. Undertaking litigation: In order to ensure the link between the research work and the outcomes sought, PSAM focused on more extensive use of litigation and official complaint mechanisms. Specifically, more aggressive use was to be made of litigation using public access to information legislation.

4. Direct engagement with the Eastern Cape Department of Health: A final avenue of intervention would be cooperative engagement with the $\mathrm{ECDOH}$ and its institutions to provide inputs into its resource management cycle and service delivery programs.

Figure 1. PSAM Theory of Change at Baseline of Case Study

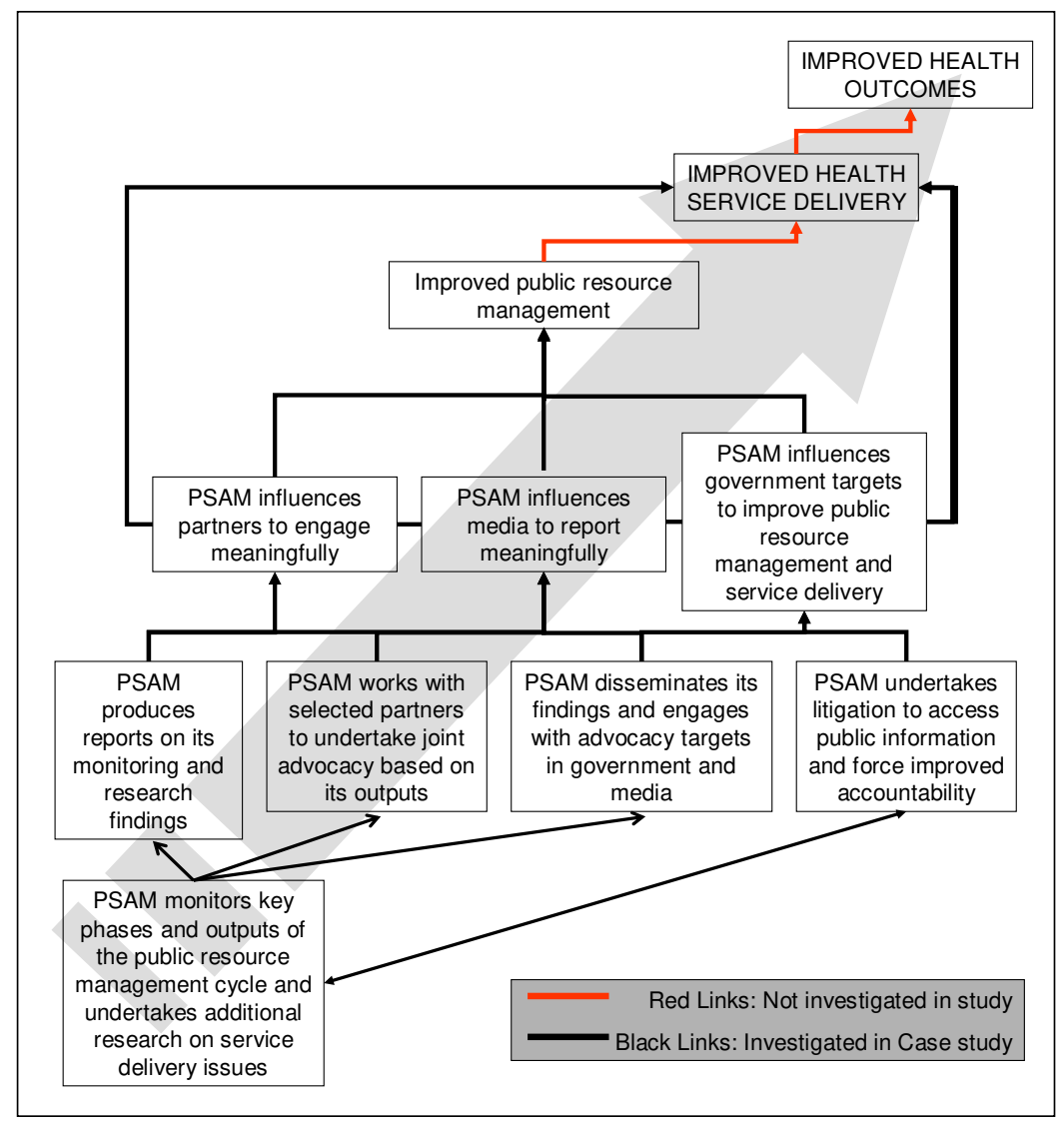

\section{0/11 Theory of Change}

Midway through the study, PSAM underwent an institutional restructuring and a thorough review of its strategies and activities. At the level of objectives, the shift was conceptual in nature. The organization's new strategic statement was now clear that enhanced service delivery was the objective (rather than the establishment of a social accountability system), and dialogue between state and citizens (the means through which the objective would be obtained). While still based on the conceptualization of the resource management cycle as the crucial and necessary underpinning for the realization of citizen's socioeconomic rights, the overall program of the organization was now aimed at "contributing to enhanced service delivery through increasingly evidence-based decision-making in public resource management processes." 
PSAM aims to achieve this by contributing to the implementation of evidence-based dialogue between civic and state actors, which it sees, in turn, as improving the management of public resources, enhancing access to public services, and leading to improved policy and legislation in relevant areas of intervention.

The most significant change, however, was in the activities and outputs of PSAM. One of the observations that had prompted PSAM to revisit its strategy was that the full set of five PSAM documentation tools was rarely produced, and indeed the impact of some of the outputs was too modest to merit the effort invested in producing them. In practice, producing all five required more capacity than PSAM had (i.e., one researcher per sector), and staff of the program found that:

- the outputs were not used as the original Framework of Change envisaged, as they tended to be lengthy, repetitive and rather dry; and

- higher impact could be achieved by engaging with the public resource management cycle through research and advocacy on specific issues in education, health, and emergency services.

The budget analysis report, however, was the one regular output that PSAM found to be used extensively (this was corroborated by the case study research). The new theory of change, therefore, envisaged that this report would still be published routinely, but that engagement with both public and nongovernmental stakeholders and the media would be driven by more ad hoc outputs linked to constant monitoring of the resource management cycle.

A key addition to the strategy was the introduction of community-based monitoring tools aimed at tracking service delivery in the health and education departments. Together with PSAM's other interventions, these were intended to help build a dialogue between citizens and state. By 2012 PSAM was setting up this part of its work program and had formed a partnership with the Eastern Cape Communication Forum to carry it out.

The 2011 changes to PSAM's strategy articulated an approach that had evolved gradually; the strategy made explicit PSAM's emphasis on evidence-based engagement and better captured the extent and nature of its research and monitoring activities. PSAM was also restructured. The separation of PSAM from its academic and training program was removed, and the organization was integrated into one coherent institution with three teams. At the same time, the organization also made the decision to formalize its relationship with Rhodes University, with which it had been affiliated since PSAM's inception in 1999.

\section{The Campaign: Implementing PSAM's Program in the Health Sector}

When the case study was initiated in 2009, the PSAM's program in the health sector was progressing reasonably well, but was constrained by having only one researcher and by the demands of producing the routine outputs.

\section{Activities undertaken by PSAM}

This section described the activities undertaken by the program (by each activity block in the organization's theory of change).

PSAM produces reports on from its monitoring work and research

- PSAM produced Budget Analysis Reports (2007-08, 2008-09, 2009-10, and 2010-11), Strategic Plan Evaluation Reports (2007-08, 2008-09, 2009-10, and 2010-11), a Performance Monitoring Report (2007-08), Expenditure Tracking Reports (2007-08 and 2008-09), and Research Reports (2007-08 and 2008-09).

- In 2007-08 PSAM researched the provision of HIV/AIDS services in specific localities, and used the findings in its HIV/AIDS advocacy campaign. The findings were also taken up by the Treatment Action Campaign (TAC). 
- In 2009-10 PSAM did preliminary investigations into failings within the Emergency Medical Service of the Province. The ECDoH agreed at the time to cooperate on the proposed research, providing PSAM access to emergency vehicles to check on the availability of supplies (that had been budgeted and paid for). However, it advised that PSAM should first seek ethics approval from Rhodes University, which PSAM did. However, the research program was not completed as the health researcher's time was taken up with other pressing work during 2010, and he resigned in 2011 to take up a position in a sister organization at national level.

PSAM works with selected partners to undertake advocacy based on its research outputs

- PSAM gave briefings and presentations to strategic partners, including to TAC (2009), COSATU shop stewards (2009), the budget and expenditure management forum of an informal CSO group on health, and to the provincial Social and Economic Committee.

- PSAM undertook a joint public expenditure tracking survey in cooperation with the provincial research and advocacy arm of COSATU in 2009, utilizing COSATU members at ground level. The initiative, however, was not completed on account of poor returns of responses and doubts as to the objectivity of responses, which were not collected by independent researchers or surveys (COSATU is itself a labor union and an important actor within the health sector). PSAM's current strategy aims to continue tracking service delivery on the ground, but through community-based monitoring tools.

- In 2012 PSAM engaged with the Eastern Cape Communication Forum and NGO Coalition to initiate its community-based monitoring program.

PSAM disseminates its findings and engages with advocacy targets in government and media

- Briefings and presentations to advocacy targets, including the Budget and Finance and Public Accounts Committees of the provincial legislature (2010); public officials in meetings arranged with the ECDoH, e.g., to the budget unit in 2009 and the Provincial Treasury (2010); and the provincial Social and Economic Committee. While the research identified ongoing instances of engagement between PSAM and public officials in the executive, it also showed that engagement with the legislature was rare. A decade ago, the legislature was a key partnership for the then PSAM — PSAM, for example, was very active in the Network Against Corruption set up by the Speaker of the Provincial Legislature. While PSAM has not ceased working with the legislature entirely, it has in recent years been less proactive in engaging the provincial legislature and its committees. This is based on its perception that it has not had much success in influencing public resource management and health service delivery through the legislature, as the capacity of the legislature to hold the executive to account is constrained by the dominance of the leading political party in it, and the internal politics of the party in the Eastern Cape. Still, PSAM maintains the legislature on its dissemination list and participates in legislative meetings when appropriate or as requested. PSAM also has sought to engage with researchers in the legislature, for example, by providing them with its materials and establishing relationships.

- Providing direct support to the ECDoH - after PSAM's 2008-09 Strategic Plan Evaluation Report — to help develop the department's new five-year Strategic Plan.

- Making submissions to the National Department of Cooperative Governance and Traditional Affairs on disciplinary codes and procedures for senior managers at provincial level.

- Issuing several press releases related to health issues in the Eastern Cape, based on the program's research. The table below details the health-related press releases over the case study period. It illustrates the extent to which PSAM has highlighted planning and budgeting shortfalls, maladministration, and fraud and corruption in the ECDoH through the media since 2007. All of the statements were published in the Eastern Cape media, and some in the national media.

Table 1. PSAM health-related press releases 2007-2011

Feb-07 Statement on poor coverage of HIV/AIDS targets in the Premier's State of the Province Speech

Mar-07 Statement on insufficiency of Eastern Cape HIV/AIDS budgets 


\begin{tabular}{|c|l|}
\hline May-07 & Statement on the Eastern Cape Health budget for 2007-08 \\
\hline Jul-07 & $\begin{array}{l}\text { Statement condemning the MEC for Health, who prevented the provincial health portfolio committee from } \\
\text { meeting with the management of a distressed hospital } \\
\text { Statement on a hospital crisis at Frere }\end{array}$ \\
\hline Aug-07 & $\begin{array}{l}\text { Statement of HIV Budget } \\
\text { Statement to condemn the suspension of a whistleblower in the health sector }\end{array}$ \\
\hline Nov-07 & Poor provision for TB patients in provincial strategic plans and budgets \\
\hline Feb-08 & $\begin{array}{l}\text { Statement on PSAM's request to the National Cabinet to intervene in the ECDoH, calling for a stop to the } \\
\text { ECDoH's intention to demolish health physical infrastructure }\end{array}$ \\
\hline Apr-08 & Call for intervention in the ECDoH \\
\hline Jun-08 & Statement on PSAM's complaint against the ECDoH to the Human Rights Commission \\
\hline Sep-08 & Statement calling for action against department head \\
\hline Feb-09 & Statement on provincial budget highlighting capacity issues in the department of health, among other issues \\
\hline Oct-09 & Statement detailing continued financial mismanagement in the ECDoH based on the latest AG report \\
\hline Mar-10 & Joint statement by TAC and PSAM on the implementation of the occupation-specific dispensation \\
\hline Feb-10 & $\begin{array}{l}\text { Statement welcoming the freezing of officials' salaries who did not disclose their assets as required by the } \\
\text { code of conduct }\end{array}$ \\
\hline Feb-10 & Call for intervention in the ECDoH \\
\hline Sep-10 & $\begin{array}{l}\text { Call for increased funds from the Provincial Treasury for provincial hospitals operational spending given } \\
\text { personnel spending stress in the health budget }\end{array}$ \\
\hline Mar-11 & Welcoming the forensic audit into the ECDoH and calling for politicians to take action \\
\hline
\end{tabular}

- Additionally, the PSAM health researcher or media liaison were frequently asked to provide ad hoc comments on issues in the health sector, both nationally and provincially, for example;

o in 2012, on the investigation of the health Superintendent General (SG) and a salary hike for the SG;

o in 2011, on exposed fraud in the ECDoH;

○ in 2010, on exposés relating to health investigations, baby deaths in hospitals, debt of the health department, probes of health tenders, additional request to support health financing in the Eastern Cape, collapse of health service in the Eastern Cape (six instances), cutting of utility services to the ECDoH headquarters, high salary costs and low operational financing in health, rationing of health care packages, and health bailouts;

o in 2009, on the crisis in Eastern Cape emergency services, staff crisis in hospitals, medicine negligence costing millions in the Eastern Cape, financial mismanagement in health, the charging of a Bhisho hospital boss, and the exit of the then SG from the ECDoH;

○ in 2008, on the high incidence of infant deaths in Eastern Cape hospitals (eight instances throughout year), poor service delivery (three instances), and mismanagement (three instances) in the health department, on complaints from nurses about the ECDoH, on threatened strikes by doctors, on specific litigation for negligence against the ECDoH, on the requirement for intervention by the national government in the provincial department (four instances), hospital generators, incompetence of the MEC for Health, and the provincial health budget; and

○ in 2007, on plans to shut provincial hospitals, on HIV/AIDS treatment and facilities, on the debacle around the national Minister of Health (18 instances), the firing of a whistleblower in the Eastern Cape (six instances), failure to monitor Eastern Cape health funds, doctor strikes, the bungling of the HIV/AIDS program funds, infant deaths in Eastern Cape hospitals (four instances), demands by labor that the MEC be fired, unavailability of antiretroviral medicines, and the inadequacy of the provincial HIV/AIDS budgets.

The extent of commentary requested provides an indication of the perceived validity of PSAM's views and the potential extent of its influence. 
PSAM undertakes litigation to access public information and force improved accountability

- The use of litigation and formal complaint procedures is part of PSAM's practice when required. For example, it used access to information laws to obtain HIV/AIDS business plans, the performance agreements of senior managers, and drafts of strategic plans.

- The program also initiated procedures in 2008 through the National Cabinet Secretariat to request that the national government intervene in terms of Section 100 of the Constitution based on there being no response by the ECDoH or provincial government over several years to serious findings by the Auditor General. When PSAM received no response, it lodged a formal complaint with the Human Rights Commission in July 2008.

- The program submitted a complaint to Independent Regulatory Board for Auditors against privately contracted internal auditors in the $\mathrm{ECDoH}$, based on findings in the Auditor General reports.

It is noticeable from the above list that PSAM's activities in the health sector tapered off from 2011 onwards. This is because the organization's main and only health researcher took another post in the first quarter of 2011, effectively halting the outputs of the health program for the latter half of the research period. While a new appointment was made in July 2011, the new researcher spent the first months attending PSAM's social accountability courses and in-house training. In addition to this change in staff, the head of the monitoring program also moved to another organization in May 2011, further reducing the program's productivity, especially its litigation advocacy. At the time of writing, the 2012-13 Budget Analysis by the health program had just been completed and distributed to stakeholders in the province.

The impact of the program's slowdown was already evident in the 2011 fieldwork. Respondents in the $\mathrm{ECDoH}$, provincial treasury and legislature regretted the absence of PSAM health outputs related to the budget and strategic plan for the 2011-12 year. While these same respondents noted in 2010 that they did not receive PSAM outputs as a matter of course, they knew where to find them on PSAM's website. Respondents in 2011 noted that the documents had not been distributed or made available. While it is unfortunate that the program was interrupted in this way, the fact that respondents in $2011 \mathrm{knew}$ that the outputs were not available suggests that they had valued PSAM's earlier outputs.

The consequences of staff turnover at PSAM also illustrates an important point about the organization's strategy. PSAM's success depends significantly on relationships of trust with its strategic partners, journalists, public officials, and members of the legislature. While training new staff members in the technical requirements of research work may only require weeks, rebuilding these relationships takes more time. Yet staff turnover is a constant. The lack of consistent, secure and long-term funding results in PSAM's inability to provide long-term salary progression and career paths to personnel and to deepen its staff complement so that the organization can do succession planning and facilitate continuity. Furthermore, given its national profile, the organization becomes a victim of its own success; as soon as it has developed a staff member to the point where they have a provincial and national profile, they take up a more lucrative position elsewhere (though often continuing the work of PSAM).

\section{Issues Covered by PSAM}

PSAM has raised the following issues in its reports, presentations, and media engagements with respect to the ECDoH:

- the poor quality of planning documentation, particularly the lack, or poor quality, of situational analysis; inconsistencies in the plans between objectives, targets, and funding; and weak formulation of monitoring and evaluation measures;

- weak budgeting in the department, with budgets not reflecting crises in previous and current budget years, or departmental objectives, as expressed in strategic plans. PSAM analysis often referred to the systemic issues that affect the $\mathrm{ECDoH}$, including nationally mandated increases in remuneration 
costs leading to overspending, pressure on non-personnel budgets, and underspending of capital allocations;

- unfunded mandates and underfunding of the $\mathrm{ECDoH}$ and the health sector by the provincial Treasury;

- very weak financial and supply chain management in the $\mathrm{ECDoH}$, coupled with high levels of unauthorized, fruitless, and wasteful expenditure;

- The apparent lack of accountability in the $\mathrm{ECDoH}$, with lack of response to Auditor General and Public Accounts Committee findings and recommendations; weak integrity management with poor follow up on disciplinary cases, and high risk for whistle-blowers; and

- poor capacity in the ECDoH for financial and general management, as well as lack of leadership.

This case study argues below that with respect to planning protocols, lack of accountability, and integrity management, positive changes occurred during the period of the case study. However, in terms of the quality of budgeting, adequate funding of the $\mathrm{ECDoH}$, issues with the structure of the service delivery platform, and its cost as well as capacity, significant and lasting changes have not been achieved.

\section{PSAM influence on strategic partners and advocacy targets}

In the 2010 and 2011 fieldwork for the case study, respondents reported the following uses of PSAM outputs (interviews 2010 and 2011, see list of interviewees in Annex 2):

- The ECDoH used the strategic plan evaluation and budget analysis to improve its strategic plans and in budget discussions.

- The provincial Treasury used the budget analysis outputs of PSAM in its internal discussions.

- The provincial Office of the Premier said that it sees PSAM as an important resource for the province and that its outputs and participation have influenced provincial processes.

- Lawmakers used the outputs of PSAM and its input into legislative oversight processes extensively. The perspective of PSAM — and its emphasis on evidence as a basis for its assessments of the policy and public financial management performance of departments - was considered valuable by committee members. Respondents from the budget and health committees remarked that they do not receive the outputs regularly and that they would like to engage more frequently with PSAM.

- Civic partners used the outputs to inform their own advocacy programs. COSATU has used PSAM's outputs to inform its strategic engagement within the tripartite alliance of government and in policy and oversight processes in the province. For the Legal Resources Centre, PSAM is an important partner on account of its research access and legal capacity, although so far most of their joint work has been in education.

- Media respondents, both at the provincial and national levels, were highly complimentary of PSAM and expressed their appreciation for PSAM's approach and professionalism. PSAM was seen as a valuable resource for objective viewpoints and as a sounding board for investigations, as it was able to back up its inputs with research and would decline to comment if it felt it was not competent to do so. One media respondent pointed out that PSAM has been instrumental in raising the profile of the Auditor General's reports in the province. PSAM shares this perspective, noting that prior to its drawing attention to the audit reports, the reports were not commonly covered in the media and very few commentators referred to them.

These responses suggest that while the health program was active PSAM was able to achieve its goals to build oversight capacity and to support stakeholders. It should also be noted that while the program was never fully implemented as envisaged due to limited resources and capacity, much of the desired effects were nonetheless achieved. Though constrained by its small staff, PSAM appears to have produced a volume of work that is both large enough and persuasive enough to have had an influence on the management of health resources. 


\section{The Outcome: Changes Observed at the Department of Health}

Between 2007 and 2012 (the period reviewed by the case study research) significant changes occurred in the budget and public financial management practices of the Eastern Cape Department of Health. This case study argues that whereas the changes cannot be attributed directly to the work of PSAM, there is sufficient evidence to support a conclusion that PSAM's work supported change indirectly. The period can be divided in two phases: a first phase from 2007 to 2010, when some change occurred, while other areas remained stagnant and even worsened, and a second phase from 2010 to 2012, which is characterized by some clear improvements in planning, budgeting, and financial management.

\section{Changes in budgets, budget processes, and service delivery, 2007 to 2010}

The following changes were observed, mapped to key functions in the resource management cycle.

Improvements in planning and budgeting: The first phase of the case study period saw improvements in the planning documentation of the ECDoH. Particularly, the situational analysis and assessment of previous budgets which were included in the five-year strategic plan 2009-10 to 2013-14 were an improvement over the previous medium-term plan (Eastern Cape Department of Health 2010). Improvements in the Annual Performance Plans were also noted, including moving from annual operational planning to three-year rolling plans that can be linked to budgets (2009-10 plan), the inclusion of more detailed information on human resources and human resource shortfalls as a basis for planning (2008-09 plan), and much improved information on conditional grant and donor grants funding (2010-11 plan)..$^{30}$

However, planning documentation continued to be of poor quality in other respects. The Annual Performance Plans did not allow policies and policy changes to be identified; the plans were not clearly integrated with the five-year plan or with other sector plans, such as the HIV/AIDS strategy, with inconsistencies in baseline data and targets; targets set in national plans were not reproduced or reported; epidemiological data were out of date and not sufficiently comprehensive; and little account was given of findings by the Auditor General in the previous year, or how shortcomings would be addressed. Some gains made in the 2008-09 documents - for example, those around using extensive human resource data — were reversed in subsequent documents. ${ }^{31}$

Furthermore, the period saw a worsening in budget credibility. As shown in the graph below in which total net variance between actual spending and revised budgets is presented by the solid line, the aggregate gap reversed (from underspending to overspending) and grew significantly in extent (from net R56 million to R316 million). However, if both underspending and overspending is taken into account, the net variance of R837 million in 2007-08 grew to R1.95 billion in 2009-10, with massive overspending on personnel in this year, resulting in underspending on the capital, other recurrent, and transfer budgets.

Overspending on personnel had two root causes: the implementation of the occupation-specific dispensation (a negotiated wage agreement to introduce new salary structures in the health sector specific to professional occupations), which raised professional salaries, and once-off backdated payments that redressed inequalities in salaries between different provincial administrations that should have been eliminated in 1996.

\footnotetext{
${ }^{30}$ Eagar 2009 and 2010.

${ }^{31}$ Eastern Cape Department of Health, "Annual Performance Plan 2008/9," Bisho, Eastern Cape Department of Health, 2008; Eastern Cape Department of Health, "Annual Performance Plan 2009/10," Bisho, Eastern Cape Department of Health, 2009; Eastern Cape Department of health, "Annual Performance Plan 2010/11” Bisho, Eastern Cape Department of Health, 2010; and Eagar 2009 and 2010.
} 
Figure 1. Budget credibility: variance between revised allocations and actual spending Eastern Cape Department of Health 2007/8 to 2009/10

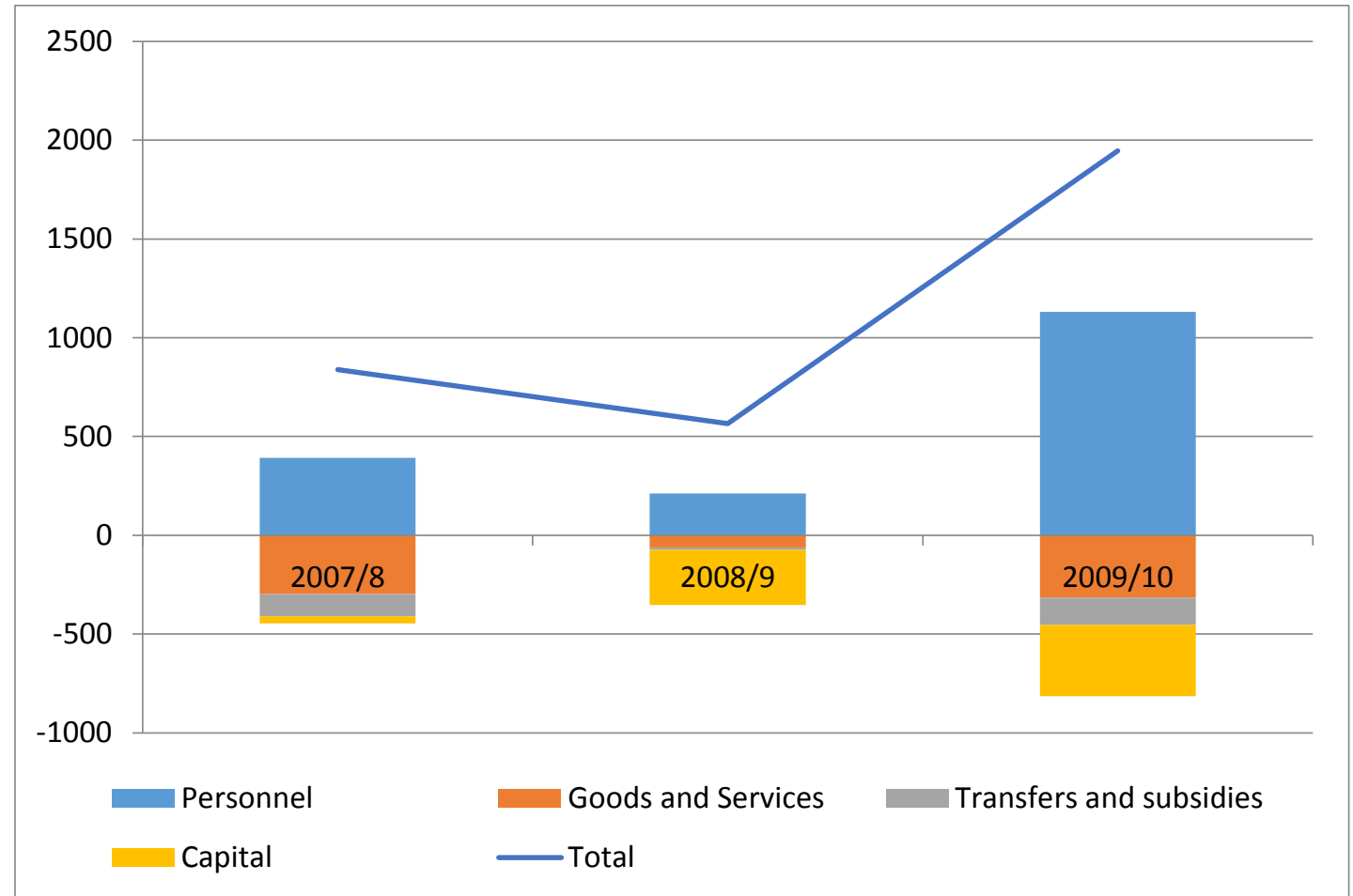

Source: Provincial Budget Statements 2007-08, 2008-09, 2009-10, 2010-11, and 2011-12.

Allocations in this period continued to reflect stated priorities poorly. According to the Provincial Budget Statement for 2009-10, the resources allocated to district health services and the HIV/AIDS programs decreased in real terms in the 2009-10 budget, despite the ECDoH stating that these were service delivery priorities. Allocations to the health administration program, however, increased significantly.

Improvements in financial and supply chain management and accountability: Accountability and financial management also remained weak. The Auditor General gave the Eastern Cape Health Department a "disclaimer of opinion" for the twelfth year in a row in 2009-10.32 This is the worst possible audit outcome and means that the Auditor General was not able to obtain sufficient audit evidence to provide a basis for an audit opinion. Specific reasons included (with the year in which it was first raised by the Auditor General in brackets) were:

- irregular expenditure was understated by R2.1 billion (equal to 24 percent of total expenditure by the department in the year) and the possibility of irregular expenditure occurring due to fraud could not be excluded;

- fruitless and wasteful expenditure was understated by R10.4 million;

- the commitments schedule did not contain sufficient relevant information to trace tenders awarded. The Auditor General was not able to confirm the completeness, accuracy or validity of the commitments disclosed in the financial statements (2004-05);

- there were inadequate records of outstanding payments at year end, and where records did exist, they were inaccurate (2004-05);

\footnotetext{
32 Eastern Cape Department of Health, "Annual Report 2009/10," Bhisho, Eastern Cape Department of Health, 2010.
} 
- leave and employee benefit records were incomplete, as well as records on the occupation-specific dispensation payments, accruals, and contingent liabilities (2004-05 for leave and employment records and contingent liabilities, 2006-07 for benefits, 2008-09 for accruals and contingent liabilities);

- incorrect payments were made to employees and not stated correctly in the financial statements (2005-06);

- It was not possible to determine the extent to which movable assets may have been misappropriated, as asset registers were not complete and accurate (2005-06); and

- the risk of fraud could not be excluded in the audit of revenue, with incomplete records kept and records not submitted for auditing (2004-05).

In 2009-10 the ECDoH had the highest share of irregular expenditure in the province as a result of supply chain management irregularities. The Auditor General's consolidated report for the Eastern Cape government explicitly refers to audit recommendations arising from previous reports, which management "has also failed to address and rectify." 33

In the report on the $\mathrm{ECDoH}$, the Auditor General also found that 86 percent of performance indicators could not be verified and that the Superintendent General (the head of the department) had failed to establish a functional performance monitoring system. The report pointed out several specific failures to adhere to relevant legislation, including the Public Finance Management Act (1999), as well as leadership, internal control, risk management, governance, record-keeping, and reporting failures.

A report commissioned by the national Minister of Health found that there "is a lack of cohesion between policy formulation, budgets and resources to implement the policies and planning." 34 Key shortcomings in leadership and strategic planning, budgeting, financial and supply chain management, human resource management, and monitoring and evaluation were also found.

\section{Changes in budgets and budget processes 2010 to 2012}

In May 2009 the contract of the ECDoH Superintendent General, who had been at the helm of the department for six years, was not renewed. This paved the way for the appointment of a new Superintendent General in January 2010, marking the beginning of a new period in the budget and financial management practices of the department.

Changes in the leadership of departments in the Eastern Cape - either at political or at administrative level - are frequent but do not often result in improved financial management or service delivery. Yet, in the case of the $\mathrm{ECDoH}$, the appointment of the new Superintendent General, combined with the appointment of a new MEC at the end of the 2010, resulted in significant change, particularly in terms of financial management and accountability. The $\mathrm{ECDoH}$, however, still faces severe challenges with respect to the adequacy of its budgets and addressing the mismatch between its funding, its service delivery platform, and its service delivery mandates and parameters as determined by national policies.

While PSAM's work in this period may have helped to strengthen financial management practices and accountability mechanisms in the $\mathrm{ECDoH}$, the same cannot be said of its efforts to improve the links between plans and budgets, to address funding and capacity shortfalls, or to address the systemic issues that affect the ability of the ECDoH to use its resources optimally.

\footnotetext{
33 Auditor General of South Africa, "Consolidated Audit Findings for the Eastern Cape Province 2010/11," Pretoria, 2011 , p. 23.

34 Peter Barron, Regina Broekman, et al., "Eastern Cape Department of Health: Report of the Integrated Support Team," Report commissioned by the National Minister of Health, Barbara Hogan, 2010, p. 10.
} 
Planning and Budgeting: In order to assess whether planning and budgeting had improved, the research tracked Program II (district health services) from the five-year Strategic Plan (SP, drafted in 2009), through the Annual Performance Plan (APP, for 2012-13), to the Budget Statement (BS, for 2012-13).

\section{Figure 2. Eastern Cape Health Department budget by program 2007-08 to 2013-14 (nominal)}

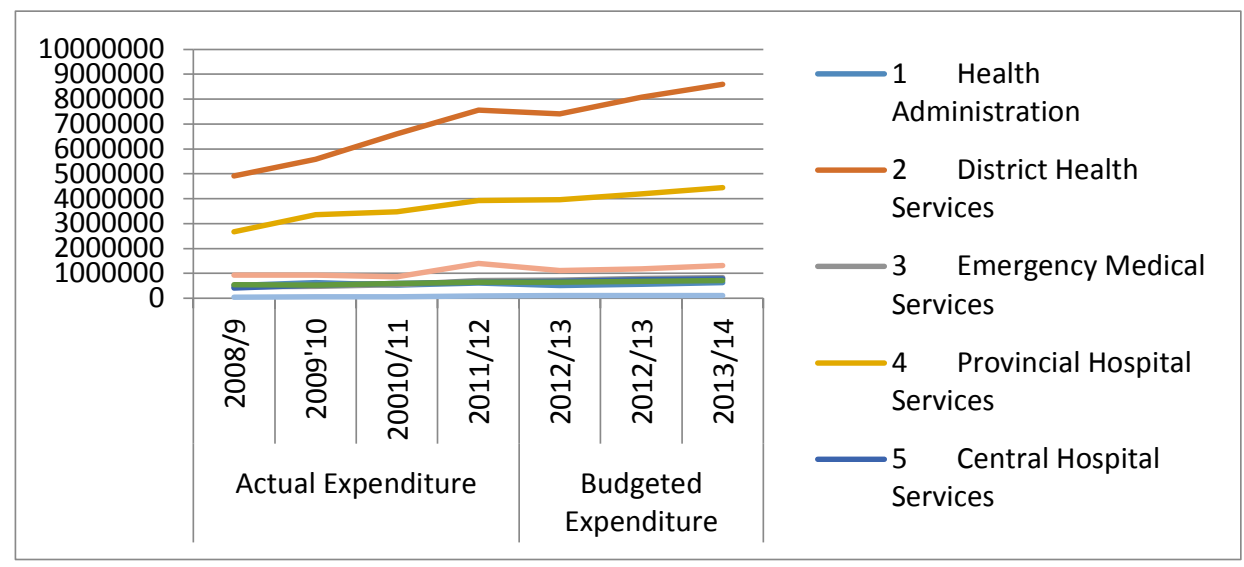

The earlier improvements in planning documentation were sustained in the second period. ${ }^{35}$ The statement of strategic priorities for the APP is consistent with the SP for the program and it updates the priorities, given changes in the environment, as required. The APP furthermore undertakes a detailed situational analysis for the program, which in the SP was done up front for the health sector as whole. The statement of priorities in the APP is accompanied by specific, quantitative targets over the three years, which are set out per program to align with the budget statement, and targets derived from national strategies are distinguished from those from provincial strategies.

However, the link between plans and budgets does not seem to have strengthened, despite efforts to allocate more money for priority programs, with apparent underfunding of the sector and weak links between targeted performance and available funds. District health services, provincial hospitals and investment in infrastructure were prioritized over the medium term in line with the SP and APP of the ECDoH (see graph below). However, these increases do not fully reflect the ECDoH's expenditure responsibilities, and the ECDoH continues to be managed in crisis mode. The rapid growth in the first two areas is on account of increases in remuneration, over which the $\mathrm{ECDoH}$ has little control given that remuneration is negotiated at the national level. The 2009-10 jump is similarly the result of an unfunded mandate as it was the result of nationally imposed remuneration increases and historical adjustments. ${ }^{36}$ In 2012 the ECDoH indicated that it was unable to implement its strategic plans due to severe underfunding by the provincial Treasury, given the carry-through effect of these mandates. In real terms its budget has barely increased. ${ }^{37}$

Furthermore, the setting of targets in the APP does not take into account this cash crunch. For example, the negative growth between the revised estimate for 2011-12 and 2012-13 is not reflected in an adjustment in targets. It is difficult to see how the targets would be achieved.

\footnotetext{
${ }^{35}$ Eastern Cape Department of Health, "Annual Performance Plan," Bhisho, Eastern Cape Department of Health, 2009; Eastern Cape Department of Health, "Strategic Plan 2009/10 to 2013/14," Bhisho, Eastern Cape Department of Health, 2010; and Eastern Cape Department of Health, "Annual Performance Plan," Bhisho, Eastern Cape Department of Health, 2012.

36 Daygan Eagar, "Financial Crisis in the Eastern Cape Health Department," Section 27, Johannesburg, 2012.

37 This is also the view of Section 27, a national CSO working on social sector service delivery, according to whom "the Province and Provincial Treasury is guilty of underfunding the Department going into the 2012-13 fiscal year given the size of its service delivery platform, the hangover of overdraft debt given the 2009-10 shock and failure to provide a further overdraft, payment for which is being withheld by the Provincial Treasury from the Department's cash transfers.," ibid.
} 
Systemic issues affecting budgeting and service delivery: The efforts to adjust the ECDoH's budget to better reflect service delivery priorities are linked to a push that began in 2010 for greater efficiency and improved service delivery throughout the ECDoH. For example, the ambulance fleet has been expanded from 58 to 460 vehicles, a skill-upgrading program is underway, slow response rates in blood and pathology services have been addressed, and, as of May 2012, doctors and specialists are being actively recruited to improve service delivery. .38

These direct service delivery interventions are complemented by a longer-term reform program, which is aimed at improving the effectiveness and efficiency of spending and service delivery sustainability through a series of systemic improvements. The longer-term reform sought to address supply chain management, rationalize the service delivery platform (by reducing the number of secondary hospitals and investing more in primary health services, for example), and decentralize budgets and delegate authority (see box below). ${ }^{39}$ The implementation of this reform program, however, has been frustrated by lack of funding and resistance by the unions. For example, in May 2012 the Provincial Treasury put a moratorium on the recruitment of personnel and in July it took over the management of personnel to ensure that the moratorium is implemented. Meanwhile, plans to rationalize the service delivery platform were frustrated by the unions (see box below on different roles of the unions).

\section{Box 2. The role of trade unions in the national and provincial political economy}

The role of unions in supporting or undermining service delivery improvements in the Eastern Cape Province has long been contentious. In 2003 an Interim Management Team found that unions had undue influence over the managers of health institutions, and that there was a culture of ill-discipline and a poor work ethic. ${ }^{1}$ In the education sector, the unions have been accused of paralyzing school management and leadership, with negative consequences for effective teaching and learning. ${ }^{2}$

The unions - and particularly the umbrella union Cosatu — play different roles in the South African political economy. Besides the traditional role of representing workers in labor negotiations through its affiliate unions, Cosatu is an important force in party politics, a formidable lobby group, and economically influential by virtue of the capital investments that it makes with its members' pension funds.

Politically, Cosatu is important because it is one of the three partners in the governing ANC Alliance. In effect, Cosatu and its major affiliates, such as the National Health and Allied Workers Union (Nehawu), are part and parcel of the governing party. Its support — or lack thereof — for the leadership bids of individuals within the ANC nationally or provincially plays an important role in whether efforts to improve public services are supported, depending on the origin of the intervention. At the same time, Cosatu has also fashioned itself as a nongovernmental advocacy organization speaking on behalf of the poor. It is in this guise that it is a social partner of PSAM.

Union members are themselves active, though their activism at times veers toward militancy. Union members often join popular marches around social issues, and labor strikes are common. These strikes, however, have frequently been marred by violence.

${ }^{38}$ C. Bateman, "Corruption busting: a real health threat," South African Medical Journal, 2011; pp. 101, 360-362.

39 The period after 1994 has seen significant growth in the number of primary health care facilities and secondary hospitals but without the necessary personnel and stocks. Often new facilities would be added on account of promises by politicians, but without the commensurate budget to staff and stock them. Peter Barron, Reginald Broekman, et al., "Eastern Cape Department of Health: Report of the Integrated Support Team," Report commissioned by the National Minister of Health, Barbara Hogan, 2010, available at:http://section27.org.za.dedi47.cpt1.host-h.net/wp-content/uploads/2010/09/Eastern-Cape.pdf. 
In the Eastern Cape key political leaders have multiple allegiances as union leaders, leaders within the ANC, and members of the South African Communist Party (SACP, the third member of the governing alliance). How these linkages play out at the provincial level are further complicated by factionalism within Cosatu itself, as well as within the ANC.

${ }^{1}$ Health Systems Trust, "Eastern Cape - Health Care Crisis," Health Systems Trust Bulletin, 2003.

2 Vuyisile Msila, "Teacher unionism and School Management: a Study of Eastern Cape Schools in South Africa," Education Management, Administration and Leadership, 2012.

Changes in financial management and accountability: While the discussion above has identified some positive trends in the quality of planning and budgeting and efforts at addressing systemic issues in the ECDoH, the most significant change has occurred in financial management and accountability.

Addressing fraud and corruption: The Eastern Cape Department of Health has long been accused of not addressing maladministration, fraud, and corruption and of ignoring Auditor General findings. ${ }^{40}$ Since the change in administrative and political leadership in 2010, however, several thousand employees of the $\mathrm{ECDoH}$ have found themselves under investigation for offenses ranging from misuse of public facilities to high corruption. By early 2012 the department had already terminated 800 employees' contracts, while the contracts of a further 300 staff were not renewed.

In 2010 the ECDoH blacklisted over 100 companies after discovering that over 200 companies on its database of suppliers shared bank accounts with at least one other on the list — allowing for fraudulent tender competitions to be set up. In addition, the ECDoH was investigating R 35 million in double payments to companies deliberately re-submitting claims for amounts already paid. ${ }^{41}$

The previous head of medical services and eight other officials were suspended for misusing the air ambulance contracted to the ECDoH for emergency services in 2010.

In November 2010 the ECDoH said that 31 department officials had been, or would be, arrested after a probe into fraud and corruption. ${ }^{42}$ The forensic audit was commissioned by the new Superintendent General and undertaken by PriceWaterhouseCoopers. Arrests at the time included nurses at a major provincial hospital for the theft of drugs and a personal assistant to the former director of primary health care.

More than 1,000 irregular staff appointments were reversed in 2011.43 Officials in the infrastructure division were also fired after irregularities in large contracts. The Superintendent General cancelled and reissued contracts for hospital refurbishment, saving R120 million (just under \$US 20 million). ${ }^{44}$

In 2011 several private doctors in the province were being investigated for buying drugs from a theft syndicate in the Mthatha Central Health Supplies Depot of the ECDoH. A day before a stock inventory was taken at the depot, it was petrol bombed. ${ }^{45}$ The inventory had been ordered as a result of the MEC receiving

\footnotetext{
40 Jay Kruuse and Derek Luyt, "Taking the Auditor General More Seriously," Centre for Social Accountability, Grahamstown, 2007.

41 "Nurses held for theft," Independent on Line, 11 November 2010.

42 "Denosa condemns medicine theft,",Media Room of the Eastern Cape Department of Health, 12 November 2010.

43 Bateman, June 2011.

${ }^{44}$ Ibid.

45 Interviews with PSAM staff, 2011.
} 
repeated reports of medicine stock-outs at health care facilities despite these medicines being purchased for distribution. ${ }^{46}$

By February 2012 both the former Superintendent General and chief financial officer had appeared in court on charges of fraud or corruption. They were accused together with 11 other high-level officials in the $\mathrm{ECDoH}$ of flouting tender procedures and paying out funds for work that was never done. ${ }^{47,48}$

In May 2012 it was reported that the probe by the Special Investigating Unit (a public entity attached to the National Department of Justice charged with investigation corruption and fraud in the public service) had revealed payments worth R42.8 million to 226 companies linked to 235 civil servants, while 174 officials' spouses were linked to companies that had collectively received R9 million (US\$100,000) in contracts.

The efforts of the Superintendent General to root out corruption in the ECDoH were supported by a multiagency working group composed of the police's priority crime investigation squad (the "Hawks"), the Special Investigating Unit, the National Prosecuting Authority, and the South African Revenue Services. ${ }^{49}$ The group is linked to the anti-corruption initiative of the Provincial Premier.

Improved budget credibility: In addition to building a culture of improved accountability, the ECDoH has put in place measures to reduce budget variance, in particular, by enforcing spending limits during budget execution. The decline in budget credibility seen during the first phase of the research period, therefore, was reversed in the second, indicated by better budgeting for 2011-12 and improved commitment control and financial management in 2011-12. The figure below shows the difference between revised budgets and actual spending for 2009-10 to 2011-12, by item of expenditure, with the total net variance indicated by a solid line. In 201112 the net R1.946 billion variance (when positive and negative variance are added, regardless of whether they result from underspending or overspending) experienced in 2009-10 declined to a net variance of R770 million.

46 Bateman, June 2011; and "Corruption Costs Eastern Cape R35 million," Eastern Cape Herald, 2011.

${ }^{47}$ Ibid; and "Five Senior Government Officials Nabbed in Eastern Cape Fraud Blitz," Mail and Guardian, 27 February 2012.

48 The former chief financial officer allegedly authorized payments totalling millions of Rands over several years in favour of companies owned by family members, totalling at least 12 companies owned by her husband, daughter, sons and sister. Zine, G. (2011). Health Sacks Finance Boss. Dispatch Online. East London.

${ }^{49}$ Interviews with PSAM staff and the Eastern Cape Department of Health, April 2011. 
Figure 3. Budget credibility: variance by main item of expenditure and net total variance 2009-10 to $2011-12^{50}$

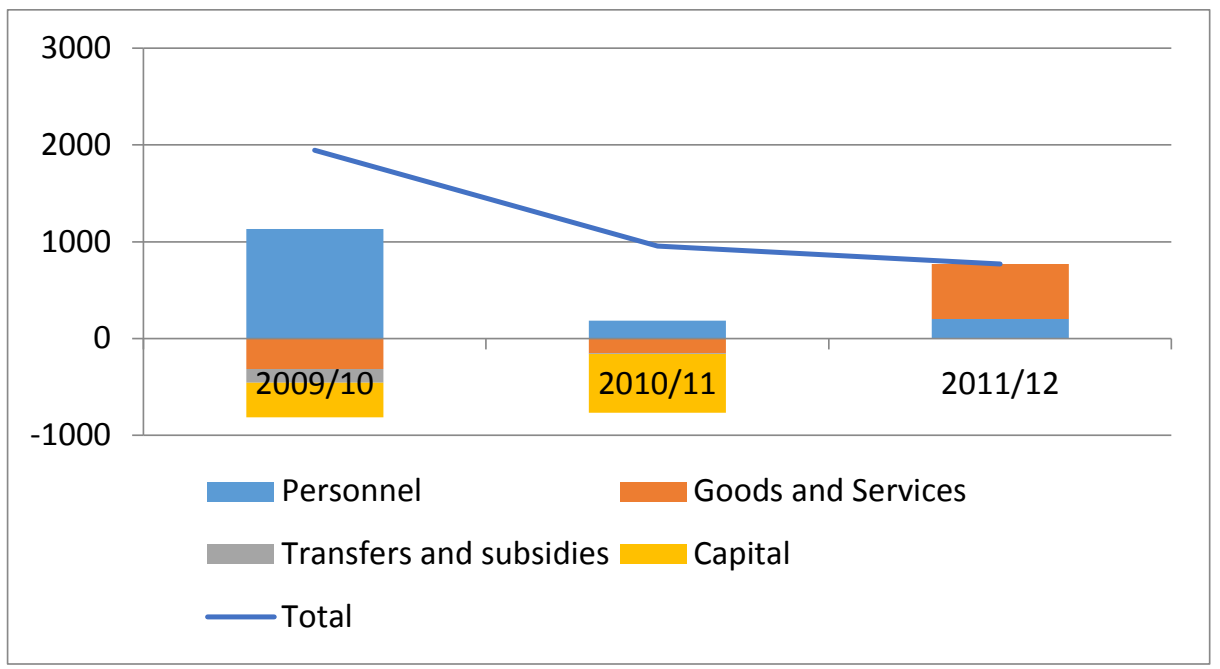

Source: Provincial Budget Statement 2009-10, 2010-11, and 2011-12.

Audit outcome improvement: The success of steps to address widespread maladministration, theft, fraud, and corruption in the $\mathrm{ECDoH}$; strengthen financial management; and introduce a culture of clean governance is evidenced by the first (for 2010-11) qualified financial audit that the ECDoH has received in the case study period, rather than a disclaimer (2009-10) or adverse opinion (2007-08 and 2008-09). ${ }^{51}$ The ECDoH's history of adverse opinions goes back more than a decade.

The improved overall outcome, however, is still far from a clean audit. All of the areas of the financial statements that received a qualification in 2009-10 were still qualified in 2010-11, except revenue, where previously raised issues had been addressed. With regard to compliance to rules and regulations and performance management information (or predetermined objectives), findings were still predominantly negative.

The extent of unauthorized and irregular expenditure, however, had declined significantly, as shown in the graph below.

\footnotetext{
${ }^{50}$ Note that for 2011-12 the revised estimate numbers were used as the audited appropriation accounts were not yet available at the time of writing.

${ }^{51}$ In the words of the Auditor General, “. . . although it still faces huge challenges, the Department of Health's movement from a long history of disclaimers to a qualified audit opinion was also the result of the leadership's commitment to a specific course of action, accompanied by regular discipline and constant monitoring. ... The most prominent move [in the Eastern Cape] relates to the fact that for the 2009-10 financial year, 73\% of the total provincial budget was disclaimed, while in the current year the figure decreased significantly to $47 \%$. This is directly related to the improved Health audit outcome," Auditor General of South Africa, "Consolidated Audit Findings for the Eastern Cape Province 2010/11,” Pretoria, 2011.
} 
Figure 4. Unauthorized, irregular, and fruitless and wasteful expenditure (2009-10 and 201011)

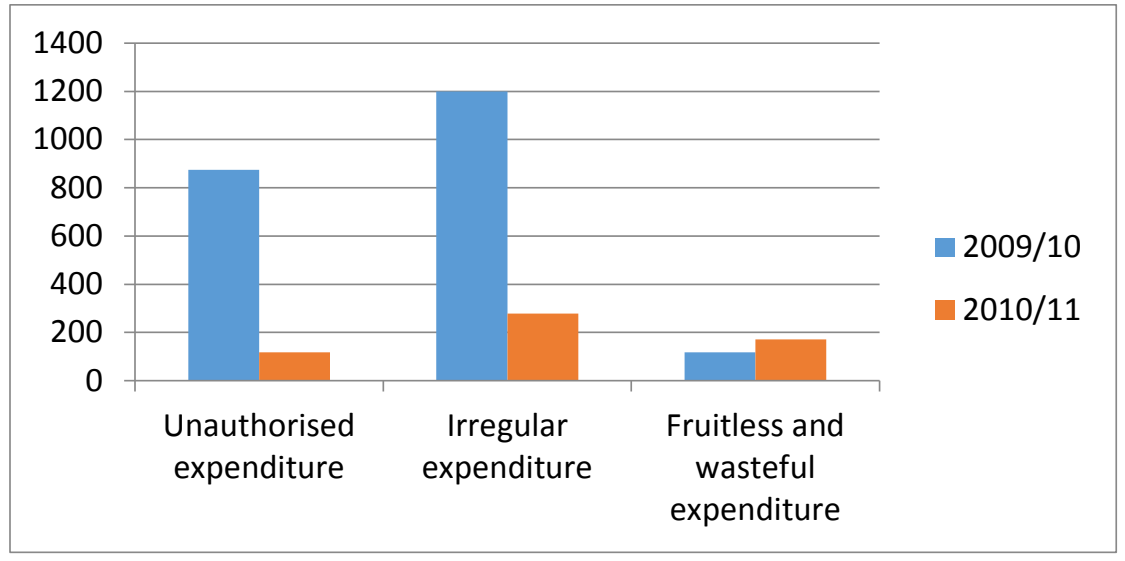

Source: Eastern Cape Department of Health 2010, AGSA 2011.

In summary, the first half of the case study period brought little change in public resource management processes and budget and financial management outcomes in the ECDoH. Some improvements in health planning and budgeting were recorded in some years, but these were vulnerable to reversal in subsequent years. In the second half of the period, however, the $\mathrm{ECDoH}$ seemed to be undergoing a turnaround with improved financial management, and actions were taken to root out maladministration, theft, fraud, and corruption in the ECDoH. Furthermore, moderate improvements in planning and budgeting were observed, though significant issues remain in relation its ability to implement its reform programs and use its resources to improve service delivery.

The improvements observed were in line with key focuses of PSAM health research and advocacy program, which were consistently the subject of research outputs, media coverage and submissions to the provincial legislature in respect of the organization. The key question remains the extent to which PSAM's work contributed to these changes in the $\mathrm{ECDoH}$.

\section{Understanding the Contribution of PSAM's Campaign}

Above, we describe changes in the public resource management cycle and outcomes for the Department of Health in the Eastern Cape. This section discusses how PSAMs health program is seen by stakeholders to have contributed to these changes.

\section{Raising public awareness through the media}

PSAM has played an important role in raising public awareness of the poor state of health resource management and service delivery in the province. ${ }^{52}$ This has contributed to a change in the ECDoH's political will to address mismanagement and weak financial management systems, and contributes to ongoing political support to the new Superintendent General. One primary pathway PSAM used to contribute to this was engaging the media. Several variables contribute to the effectiveness of this pathway.

\footnotetext{
52 Interviews with M. Rayi (Cosatu), S. Fratchet (ECDoH), M. Matomela (chair of Finance Committee, Provincial Legislature), B. Hayward (health reporter, The Herald), Prof. J. Peires (retired, University of Rhodes), and J. Walton (advocacy manager for Black Sash [national CSO] and former ANC Councillor).
} 
First, the media sees PSAM as an objective reference point on health issues in the province, a perception that is shared by respondents in the executive, the legislature, and civil society. ${ }^{53}$ While executive respondents still recall an earlier period when PSAM was more adversarial and focused on "blaming and shaming," this was usually balanced with an acknowledgement that the program has changed its approach and is now an important resource for the province. ${ }^{54}$ PSAM's affiliation with Rhodes University was seen to have helped reshape the organization's reputation as a provider of evidence-based research and analysis.

PSAM's evidence-based approach to supporting the media on health in the province is an important variable in this contribution. According to a health reporter for provincial newspaper, The Herald, "What they have to say is not reaction but research based. That makes it easier, more effective to use. It is better than just a pure reactionary organization. It is also very helpful that they can provide a legal perspective, a constitutional legal perspective based on South Africans' rights. Good to get that clear and present it to readers. When a query is outside their ambit of expertise, they do say so. They say they cannot comment; they have not researched it at all." ${ }^{55}$

Second, PSAM engages with different types of media to reach different audiences. Whereas urban or educated audiences typically read newspapers, rural or less educated audiences rely more on radio. PSAM is routinely quoted in the provincial and national print media, and its representatives are often heard on national and provincial radio. Furthermore, during the case study, PSAM strengthened its ties to community-owned radio stations, which was seen as an important building block in its dissemination strategy.

Third, PSAM's research has not only helped to keep health issues in the public domain but has helped to focus the debate on who is accountable for what (see table of press releases above and comparative table on Eastern Cape and Northern Cape health coverage below). The research has been influential in making clear the root causes of the problem. PSAM has clarified the difference between such "legitimate causes" as underfunding and a genuine backlog of capacity and "preventable causes" that are within the department's control, such as poor management and corruption..$^{56}$ In this way the research has contributed to the pressure that is felt by the Eastern Cape Provincial government to address the relevant issues. It has helped to separate out the facts of why the department is in this situation from "vague accusations of corruption." PSAM has made news reporting on health more effective. ${ }^{57}$

Overall, the dissemination of PSAM's research in the media - and its availability to journalists who were researching their own stories - is seen to have strengthened the political will in the province to address public management and service delivery issues, particularly in view of the 2011 municipal elections. ${ }^{58}$ One respondent also pointed out that the local newspaper in the seat of the Eastern Cape Government (East London/Bhisho), the Daily Dispatch, is read with great interest by key stakeholders in government and the ANC, who are sensitive to the paper's news and opinion articles. ${ }^{59}$ Extensive coverage of leadership and management failures, therefore, is experienced as an embarrassment by provincial leaders, bolstering actions taken.

\footnotetext{
${ }^{53}$ Interviews with M. Dimaza (chair of Health Committee, Provincial Legislature), Frachet, Hayward, Matomela, and J. Seaworyeh (head of Budget Office, Eastern Cape Treasury).

54 Interviews with Hayward, L. Tshoko (Strategic Planning Unit, ECDoH), Office of the Premier, and Matomela.

55 Interview with Hayward, April 2011.

56 Interviews with Fratchet, Hayward, and D. Eagar (Health researcher with PSAM, now with Section 27).

${ }^{57}$ Interview with Hayward.

5858 Authors' analysis, based on interviews with J. Kruuse (head of monitoring team at PSAM), D. Luyt (head of Communications Program, PSAM), N. Overy (Independent researcher, formerly with PSAM and former head of Department of Economic Services and Environmental Affairs), and Hayward.

${ }^{59}$ Interview with Pieres.
} 


\section{Direct influence of research in the executive}

PSAM has succeeded in complementing its efforts to improve the governance of the ECDoH through direct technical support to and the use of its products within the provincial government. PSAM's work is respected across the executive. The ECDoH respondents highlighted the degree to which its work is used; in fact, in 2010 the ECDoH asked for PSAM's assistance to review its draft health strategic plan, and subsequently implemented most of the recommendations. ${ }^{60}$ In addition to this direct engagement, PSAM's routine outputs were used for planning and budgeting processes by the executive. The Provincial Treasury reported that it uses PSAM's reports in the budget process, and key officials in the Department of Health use the budget analysis report as a key analytical reference source in decision making. Respondents reported that PSAM's analysis is high quality, relevant, and influential in a context where executive capacity to undertake the work is limited. ${ }^{61}$ Officials, who are focused on their daily administrative tasks, often do not have the time, or the skills, to undertake such research and analysis.

PSAM continues to exert influence through its former staff, as well. The previous health researcher, who is now working with another CSO, Section 27, continues to engage with the new Superintendent General on health issues in the province. Indeed, this researcher has brought further attention to the issues in the Eastern Cape at the national level, as well. ${ }^{62}$

With increased political pressure in the province to identify and address challenges, there is also increased demand for quality research, which has bolstered PSAM's political currency. This point was made by a number of executive respondents, but also clearly articulated by other respondents. ${ }^{63}$ Walton, an advocacy manager for the human rights organization Black Sash, emphasized the importance of PSAM's technical capabilities, given the dearth of such skills within the provincial administration.

In health, however, data gathered for this report show only limited correlation between the research outputs of PSAM and budgetary decisions by the executive. One exception has been the increase in funding and monitoring of key research areas, namely HIV/AIDS service delivery and emergency services. A key change that may be in the pipeline is an anticipated increase by the province of the total resources available to the $\mathrm{ECDoH}$. To date, the provincial government has not increased resources in real terms; rather, the ECDoH's available cash resources have steadily declined. ${ }^{64}$ With resources falling and the department putting in place stricter measures on spending, the result has been high-profile service delivery problems, such as stockouts in clinics and hospitals, closure of clinics, and severe staff shortages. ${ }^{65}$

\section{PSAM research leverages advocacy and other initiatives by strategic partners}

At the start of the case study, PSAM had several strong partnerships with other civil society organizations, including the Treatment Action Campaign and the AIDS Law Project. Although PSAM has not yet engaged directly with citizens, this may be a part of their future strategy through the community-based monitoring tools now being developed.

\footnotetext{
${ }^{60}$ This is acknowledged by the ECDoH in the introduction to the document.

${ }^{61}$ Interviews with Tshoko, Fratchet, Seaworyeh, and the Premiers' Office.

62 For example, a press release at the national level by Section 27 in May 2012 called for an intervention in the funding and management of the department by the national level, given that significant shortfalls between the ECDoH's available cash and the short-term, nondiscretionary cost of its service delivery platform is affecting the availability of medicines and other critical inputs in hospitals and clinics in the Province. (Daygan Eagar, "Financial Crisis in the Eastern Cape Health Department," Section27, Johannesburg, 2012.)

${ }^{63}$ Interviews with Fratchet, Tshoko, Premier's Office, Walton, and Peires.

${ }^{64}$ Thokozile Mtsolongo, "Eastern Cape Department of Health, Budget Analysis, 2012/13," Public Service Accountability Monitor, Grahamstown, 2012.

65 Ibid.
} 
Still, PSAM has been unable to forge as many research and advocacy partnerships as it had originally intended. The 2010 fieldwork found that this is largely a result of very limited human resource capacity, which means there is a trade-off between the primary activity that would support these engagements - i.e., research — and the engagements themselves. The 2012 fieldwork pointed to renewed efforts to build partnerships in the community-based monitoring program.

In spite of these shortcomings, civil society respondents still reported that the work of PSAM has helped them to lobby the executive. The Legal Resources Centre, for example, turns to PSAM when its specific expertise is required in cases; and Cosatu reported drawing on PSAM expertise and knowledge for its participation within forums of the tripartite coalition. PSAM's analysis has been used to draft inputs into the meetings on issues such as under and overspending or service delivery shortfalls. ${ }^{66}$

Overall, respondents agreed that the PSAM's work has changed the discourse of commentators, including other organizations and the media. Before PSAM launched its monitoring program, the budget cycle received only scant attention, and health service delivery issues were not routinely linked to the budget, public resource management, and oversight. PSAM heightened awareness of these issues: for example, by drawing attention to reports by the Auditor General. There is now much more media attention when the provincial government fails to respond to Auditor General recommendations. ${ }^{67}$

PSAM, however, will need to deepen its engagement and efforts to reach organizations that may affect transformation in the sector negatively. For example, the provincial leadership of Nehawu — the key union in the health sector — while aware of PSAM and the nature of its work, was not aware of PSAM's different outputs and did not make use of them.

The local regional director for the Black Sash (a civil society organization advocating justice and equality) has emphasized the positive role a skilled organization like PSAM can play in teaching community-based organizations to engage effectively with state structures. While PSAM's program so far has worked more with province-wide CSOs, the community-based programs will start to explore these approaches.

\section{Limited use of litigation and engagement with the legislature}

PSAM has used litigation to a limited extent in its health program, and primarily to gain access to information it required to monitor budget implementation.

The discussion above provides an overview of PSAM's engagement with the legislature. Though lawmakers have by and large been positive about PSAM's work and have described their use of PSAM's reports, the case study has not found evidence that this engagement contributed to the changes observed in the health department. However, at the time of writing, the health program was in the process of re-establishing ties with the legislature's health committee researcher, a former PSAM staff member. A closer integration with the help of the legislative health committee could make this component of PSAM's work more effective.

In conclusion, the primary pathways of influence for PSAM have been through the media as well as through direct engagement with the executive and through civil society partners. There is some agreement among actors in the province that PSAM has played a role in creating political space for the changes in the health department by consistently raising awareness of how delivery issues in health are related to failures in budgeting and financial management. PSAM's ability to create this space was bolstered by its reputation for objective, evidence-based analysis and its technical skills.

\footnotetext{
${ }^{66}$ Interview with Rayi.

${ }^{67}$ Interview with Hayward, 2011.
} 
Earning this reputation, of course, depended on PSAM recruiting and training appropriately skilled program staff. In this regard, the case study has demonstrated 1) how vulnerable the program is to changes in personnel (the departure of its experienced health researcher resulted in an interruption of more than a year on program activities), and 2) how limited resources constrain the degree to which the organization can mitigate against the risk of losing staff. Furthermore, limited internal capacity in PSAM has also curtailed its ability to pursue more effective partnerships with other civil society organizations and citizens and to build campaign coalitions.

\section{Informal avenues of access and influence}

Outside of PSAM's formal activities and publications, the organization and its leaders have also been active in informal ways by engaging and advocating for change through personal relationships with the provincial political and business leaders and senior public servants. These avenues of influence have been enabled by PSAM's growing reputation for objectivity and access to valid evidence, as well as through work with the Anti-Corruption Forum and Council (overseen by the Premier's Office). Furthermore, the organization's support of public officials who have faced unwarranted removal (often for political reasons or factors beyond their control) has also opened doors in the administration, allowing for its work to reach decision makers. In all of these relationships, PSAM's credibility is bolstered not only by its methodology and approach but also by its long history in the province. A key query that emerged during the research was why so much of its work is focused at the provincial level, while so many of the issues that affect service delivery in the province have their origin at the national level. PSAM justifies its focus on the provincial level by pointing out that the root cause of problems in the province has not been the funding per se but its mismanagement. In other sectors where departments have improved their budget performance (for example in Human Settlements), the organization has shifted its focus to the need for greater resources. ${ }^{68}$

\section{Alternative Explanations of Change}

While the sections above have demonstrated a clear coincidence between PSAM's health campaign and positive accountability and financial management changes in the Eastern Cape Department of Health, still be to answered are 1) whether the changes would have occurred in the absence of any activities by PSAM, and 2) why similar changes have not been experienced in other sectors where PSAM works.

One possibility is that a confluence of other factors bolstered the political will that led to the changes. During the period covered by this study, there was indeed an opening up of space for acknowledging problems in government and also growing concern in the ANC over voter behavior in the Eastern Cape.

\section{Political space in the health sector}

Until 2010, though PSAM was very active in the health sector, very little real, sustained change occurred in the $\mathrm{ECDoH}$. Despite significant evidence of corruption in the $\mathrm{ECDoH}$, a long and public history of service delivery failures, and poor budget management, hardly any senior department officials had faced any consequences for negligence, incompetence, or criminal activities. The only attempt to dismiss the Superintendent General prior to 2010 (in 2008 by the then MEC) was reversed by the premier, who relieved the MEC of his post instead.

After Polokwane (the ANC elective congress in 2007 in which Thabo Mbeki lost the leadership of the ANC to Jacob Zuma, who was later to become President) the space for accountable government seemed to open up with greater willingness in government to admit failure and tackle problems. Previously, a purging of the provincial health department would have been perceived by the previous President, Thabo Mbeki, as too

\footnotetext{
68 At the time of finalising this report, PSAM had already started to work together with other civil society organizations to address funding shortfalls in the health sector by national government. This work, however, falls outside of the fieldwork period.
} 
embarrassing for the ANC-led government, creating the circumstances for mismanagement and corruption to grow. With the appointment of Zuma, this appeared to change, which in turn created more political space to take action.

Linked to this is the argument that the change in ruling party leadership disrupted existing networks of influence in the Eastern Cape, with some individuals suddenly finding themselves without political protection. It also created the circumstances under which individuals with alleged links to the Mbeki faction in the ANC could be exposed and ousted. Shortly after Polokwane, for example, the provincial premier (who had previously protected the Superintendent General) was dismissed, together with senior members of her cabinet.

In the health sector more broadly, the gathering at Polokwane enabled change; the removal of Mbeki as the president of the ANC was soon followed by his resignation as President of the country in 2008. This resulted in the appointment of a new national Health Minister to replace Dr. M. Tshabalala-Msimang, who is widely perceived to have mismanaged the public health sector, blocking critical services such as ARV support for people living with HIV/AIDS. ${ }^{69}$ She was first replaced by Barbara Hogan, who had a reputation for open and honest engagement with issues, an attitude which might have cost her the post in 2009 when she was made Minister of Public Enterprises soon after she had publicly disagreed with government decisions..$^{70} \mathrm{Her}$ replacement, Dr A. Motsoaledi is also perceived to be driving reforms and as bringing his considerable experience in the health sector to the job. He was reported to have been instrumental in appointing the new superintendent, though he has denied having any direct influence on the provincial authorities. ${ }^{71}$

\section{Introduction of the National Health Insurance Policy}

A second change was the introduction of the National Health Insurance Policy, the implementation and success of which was predicated on significant improvements in the management, capacity, and performance of the public health sector countrywide. ${ }^{72}$ This has created a strong political and technical incentive to address longstanding challenges in the public health sector, and the reforms have become an important part of efforts by the ANC to demonstrate that it acts in the interest of the poor. Given the seriousness of the challenges in this sector in the Eastern Cape, it is not surprising that the province has been singled out for specific intervention. ${ }^{73}$ This argument is supported by the selection of Dr. Pillay for appointment as Superintendent General by Dr. Motsoaledi. ${ }^{74}$

\section{Pressure at the ballot box}

These internal ANC politics have also been driven in part by changing voter behavior in the Eastern Cape. An analysis of voting trends in the Eastern Cape illustrates this point. The graph below shows how the dominant position of the ANC in the Eastern Cape in national, provincial, and local elections in 2004 has been eroded in recent elections (the 2009 national and provincial elections and the 2011 local government elections). Speculation about voter behavior has been at the forefront of electoral battles between the ANC and other parties. For example, in the 2009 elections the Congress of the People (Cope), which formed as a splinter party of the ANC after the 2007 ANC elective congress, was seen to threaten the ANC dominance in

\footnotetext{
${ }^{69}$ Bruce Weber, "Manto Tshabalala-Msimang, South African Who Oversaw Discredited AIDS Policy, Dies at 69," The New York Times, 16 December 2009.

70 Sharon Stone, "The 2009 TIME 100: Barbara Hogan," Time Magazine, 30 April 2009.

71 Bateman, June 2011; and Chris Barron, "So Many Questions," The Sunday Times, 8 July 2012.

72 See, for example, National Department of Health,"Statement on National Health Insurance at the Health Leaders Retreat 2010," 2010, http://www.doh.gov.za/show.php?id=2116; C. Bateman "Pre-NHI Cleanup: Motsoaledi enlists private sector," South African Medical Journal, July 2011, vol. 101, no. 7, pp. 438, 440, 442; and Du Preez, L, "Medical Schemes Likely to Survive until national health system is alive and well," Personal Finance, 13 August 2011.

${ }^{73}$ Barron, et al.

${ }^{74}$ Bateman, July 2011.
} 
the province. ${ }^{75}$ In the 2011 municipal elections, the official opposition, the Democratic Alliance, was expected to make significant gains, if not take over, the metropolitan municipalities in the area.

The graph below shows the support to the ANC overall in the national elections, and support at the provincial and municipal elections since $1994 .{ }^{76}$ Significantly, support in the province has declined since 1994 in the first place, and in the second, the gap between support at the provincial level and overall support has narrowed, indicating that the party is losing support faster in the Eastern Cape than in the country overall. Important to note for this case, the replacement of the Superintendent General at the beginning of 2010 with someone handpicked by the new national Minister of Health, came shortly after the 2009 national and provincial elections.

Figure 5. Support for the ANC in the Eastern Cape, 1994 to 2009

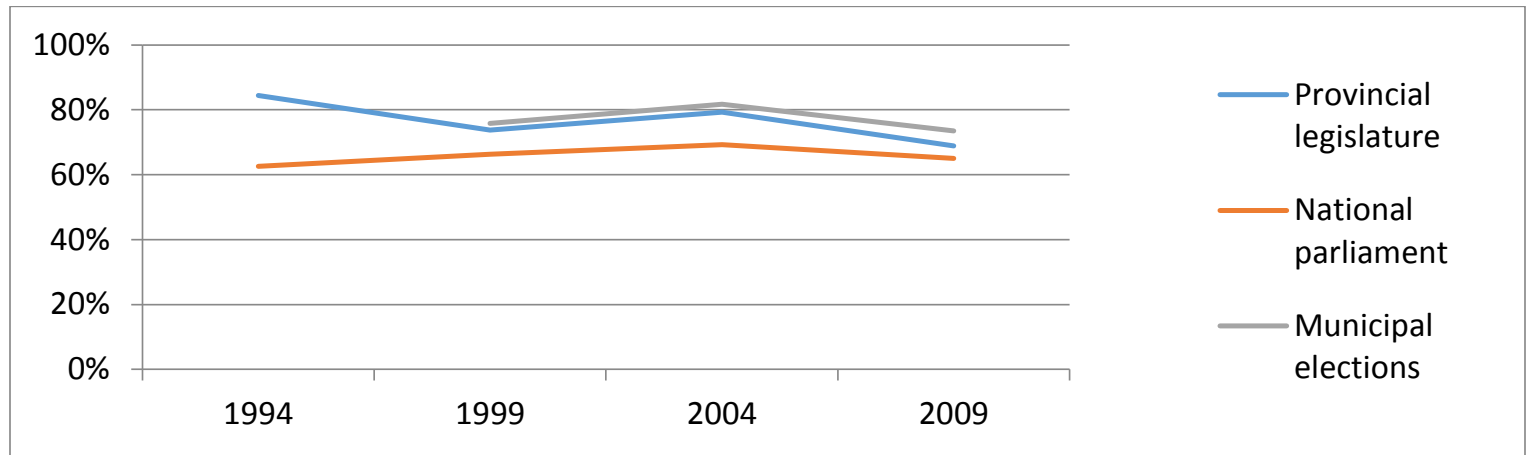

Source: Independent Electoral Commission of South Africa

\section{Why did national government only intervene in the Eastern Cape?}

This case study acknowledges the importance of the factors described above as catalysts of change. However, we argue that the work of PSAM in highlighting the extent of problems within the Eastern Cape, and their efforts to back up their statements with evidence, played a role in prioritizing the intervention in this province over other provinces. This argument is supported by a review of the public resource management performance of all eight other provinces, which reveals that other provinces had an equally dismal record in the years prior to the intervention in the Eastern Cape. Yet, similar civil society efforts were not mounted in these provinces.

The table below shows the audit performance of the nine provinces in health between 2007-08 and 2010-11. If changes would have occurred without PSAM, then it follows that the Northern Cape Province, with an audit track record worse than that of the Eastern Cape in health, should have been subject to a similar intervention. Of course, it could be argued that the health budget in the Eastern Cape is significantly larger, and affects a larger population than that in the Northern Cape. However, even in Gauteng, which has a budget that is one and a half times that of the Eastern Cape, no similar efforts were made to address a growing crisis in the health department at the time of the Eastern Cape intervention. This despite the fact that the average variance between adjusted budgeted expenditure and actual expenditure in Gauteng in the two years prior to the change in the Eastern Cape was comparable to the variance in the Eastern Cape (see table below for comparative numbers).

75 “A Political Battlefield," Mail and Guardian, 27 January 2009.

${ }^{76}$ Note that the municipal elections plotted to the national election years 1999, 2004, and 2011, took place in 2000, 2006, and 2011 respectively. 
Table 1. Health and education provincial audit outcomes 2007-08 to 2010-11

\begin{tabular}{|c|c|c|c|c|}
\hline \multicolumn{5}{|c|}{ Health } \\
\hline & 2007-08 & 2008-09 & 2009-10 & 2010-11 \\
\hline Eastern Cape & Adverse & Adverse & Disclaimer & Qualified \\
\hline Freestate & Qualified & Qualified & Disclaimer & Qualified \\
\hline Gauteng & Qualified & Disclaimer & Disclaimer & Qualified \\
\hline KwaZulu-Natal & Findings & Findings & Qualified & Qualified \\
\hline Limpopo & Qualified & Qualified & Qualified & Disclaimer \\
\hline Mpumalanga & Qualified & Qualified & Qualified & Qualified \\
\hline Northern Cape & Disclaimer & Disclaimer & Disclaimer & Disclaimer \\
\hline Northwest & Qualified & Qualified & Findings & Findings \\
\hline Western Cape & Findings & Findings & Findings & Findings \\
\hline
\end{tabular}

Table 2. Comparative size of health budgets and variance, Eastern Cape, Gauteng and Northern Cape

\begin{tabular}{|l|r|r|r|}
\hline & \multicolumn{1}{|c|}{ Spending } & Variance 2008-09 & Variance 2009-10 \\
\hline Eastern Cape & $2006-07$ to 2008-09 & $8 \%$ & $16 \%$ \\
\hline Gauteng & 39,842 & $16 \%$ & $12 \%$ \\
\hline Northern Cape & 4,706 & $22 \%$ & $11 \%$ \\
\hline
\end{tabular}

Source: Provincial Health Budget Statements, 2010-11, Eastern Cape, Gauteng, Northern Cape

An analysis of coverage of the Eastern Cape and Northern Cape health departments in a key national newspaper (the weekly Mail and Guardian) provides further support for surmising that the work of PSAM in highlighting financial mismanagement and poor audit outcomes in the Eastern Cape could have contributed to the intervention and continuing support for the new superintendent. The table below reflects the number of articles in this newspaper on this topic for each of the two provinces. Fourteen Eastern Cape articles were recorded, compared to seven for the Northern Cape. In eight of the Eastern Cape articles, PSAM was quoted, highlighting financial mismanagement and/or the audit outcomes. Furthermore, in the period between 2007 and the appointment of the Superintendent General in the Eastern Cape, only three articles appeared on the Northern Cape department's finances, compared to eight for the Eastern Cape. ${ }^{77}$

Table 3. Coverage of financial affairs of Eastern Cape and Northern Cape health departments in Mail and Guardian newspaper, 2006 to 2012

Eastern Cape
\begin{tabular}{r|l}
\hline Oct-06 & "Financial shambles in Eastern Cape, including health" (PSAM quoted) \\
\hline Apr-06 & "Health MEC should resign, mismanagement cited" (PSAM quoted) \\
\hline Apr-06 & "Audit disclaimers raised as reason for MEC's firing" (PSAM quoted) \\
\hline Aug-07 & "DA wants hospital placed under administration" \\
\hline
\end{tabular}

\footnotetext{
${ }^{77}$ Most of the articles in the Northern Cape over the full period refer to the arrest and court appearances of high ranking office holders and officials in the Northern Cape associated with the sale of equipment above market prices to health facilities in the province, uncovered in a forensic probe into the affairs of a company after a complaint to the National Treasury.
} 


\begin{tabular}{|r|l|}
\hline Aug-07 & "Gagging of officials over service delivery" (PSAM quoted on mismanagement) \\
\hline Aug-07 & $\begin{array}{l}\text { "Eastern Cape poor audit performance set out to substantiate why national minister of health should resign" } \\
\text { (PSAM quoted) }\end{array}$ \\
\hline Feb-08 & "Mismanagement in province" (PSAM quoted) \\
\hline May-09 & "Health chief fired" \\
\hline Nov-10 & $\begin{array}{l}\text { "Mismanagement of health budget and moving clinics from municipalities to the health department" (PSAM } \\
\text { quoted }\end{array}$ \\
\hline Nov-11 & "R19 billion backlog in health infrastructure, poor financial management mentioned," (source article in Daily \\
\hline Jan-12 & "Debt strapped health department cannot hire further personnel" \\
\hline Feb-12 & "Five senior officials arrested" \\
\hline May-12 & "SIU uncovers fraud" \\
\hline Jun-12 & "NHI low chance of success: poor management of health department" \\
\hline Northern Cape & \\
\hline May-07 & "DA highlights poor performance of department" \\
\hline Jul-07 & "DA notes poor administration in provincial health departments, including Northern Cape" \\
\hline Jun-07 & "DoH placed under administration by provincial treasury" \\
\hline Aug-10 & "Arrest of G Savoi, accused of tender rigging" \\
\hline Nov-10 & "ANC chair in the Northern Cape arrested linked to Savoi" \\
\hline Jan-11 & Reporting on Savoi / Block case \\
\hline Jun-11 & "Allegations of bribery and tender rigging after discovery of medical waste dump" \\
\hline
\end{tabular}

Source: Mail and Guardian, www.mg.co.za

A look at the coverage of Gauteng's Department of Health $(\mathrm{GDoH})$ further strengthens the argument of a correlation between media coverage of mismanagement in the public domain and an intervention. Between 2007 and 2010, only four articles appeared on poor financial management in the GDoH, two of which referred to consultancy contracts awarded to a firm with connections to the health MEC. This is despite the GDoH having received a qualified audit opinion and a disclaimer. During 2011, there were 10 articles that referred to tender rigging, debt build up, cash shortages, and the state of financial management in the GDoH, including references to the content of the Auditor General's report for 2010-11, and by December 2011 the national government intervened in the GDoH, after the provincial government requested a debt bailout.

The proposition, therefore, is that whereas a confluence of national and provincial political factors acted as catalysts to enable a governance turnaround in the Department of Health in the Eastern Cape, the province was singled out at the time for intervention. This can be linked to PSAM's work to keep the issue in the local and national media. Furthermore, the focus of the intervention in the first years can be linked directly to contributions made by PSAM.

\section{Why was there not a similar impact in the Eastern Cape Department of Education?}

If the work of PSAM in the provincial health department, in combination with the favorable circumstances provided by a national intervention, contributed to improving health finance management in the province, why did PSAM not achieve the same impact in the Education Department? The audit outcomes of this provincial education department (adverse in 2007-08 and 2008-09, disclaimers in 2009-10 and 2010-11) were similar to those of the $\mathrm{ECDoH}$, and as a result the national government intervened here, as well. The PSAM education sector program has also been undertaking the same activities as had the health program since 200708. As was the case for health, PSAM's outputs in the education sector have systematically detailed public resource management process shortfalls through using the same tools since 2007, with the difference being 
that the education program has been more active in litigation (see box below for a review of program activities and outputs).

On the face of it, however, there are fewer successes with which its activities can be correlated. Despite the activities of PSAM, service delivery, budget, and public financial management outcomes in this department have remained very poor. The 2010-11 Auditor General Report again provided a disclaimer, detailing unauthorized, irregular, and fruitless and wasteful expenditure running into billions of rand. ${ }^{78}$

\section{Box 3. PSAM Education Program}

The overarching objective of PSAM's education program is to strengthen the delivery of education services in the province through improvements in the public resource management cycle. As with the health program, the education program has adjusted its program of work in response to its best available avenues of influence.

For most of the case study period, the program focused on producing good research and disseminating its analysis and findings through the media and to stakeholders. The program has had particular success with its service delivery report in 2009 and a report on tracking the expenditure in the school nutrition program in 2010. These were well covered in the media and were seen as objective research.

Subsequently, the PSAM program's researcher was able to engage directly with department officials more frequently, even if the program was not necessarily seen as a partner by all of the senior leadership in the Education Department. Besides presenting the school nutrition research directly to the Office of the Premier, the program has also been invited to join the Education Department's research committee. Its role on the committee is not formalized, but it has played a supportive role setting the research agenda. Furthermore, in the beginning of 2012 the PSAM education program was approached to help refine the department's approach to its school readiness monitoring.

The PSAM education researcher concurs that (similar to the health program) the shift to a less confrontational presentation of evidence - rather than one targeting corruption and individuals — has been a key to opening doors. Even the participation of the PSAM education program in a court case brought by the Legal Resources Centre against the Education Department has not affected its cooperative relationship with some departmental officials.

However, as with the Health Department, conditions in the Department of Education for reform are tough, with entrenched networks of power resisting efforts to change. Capacity is also weak, particularly in strategic planning and budgeting, an area where the PSAM has been able to provide support.

PSAM's education program also has only one researcher, though this position has been filled consistently since 2008, meaning that it has been able to build on its direct contact with the Department of Education, something that the health program has been unable to do after the initial cooperation in 2010.

While a link can be drawn between the activities of PSAM's health program and the intervention by the National Government, the education program has not met with similar success. A key reason is the continued presence of a head of department who did not welcome national intervention, and the timing of the intervention so close to the next ANC elective conference, making it more vulnerable to factionalism within the ANC.

\section{Box 4. Factors affecting the efficacy of the education intervention}

The takeover by the national Department of Basic Education of the provincial Education Department under Section 100 of the Constitution was later suspended by President Jacob Zuma in 2011, after the Minister of Basic Education reported that little headway had been made. Instead, the President appointed a team of five national and five provincial ministers to monitor the department. ${ }^{1}$

${ }^{78}$ Auditor General of South Africa, "Consolidated Audit Findings for the Eastern Cape Province 2010/11," Pretoria, 2011. 
A key figure in resisting the intervention and blocking activities of national government officials was the head of the department, who was the preferred candidate of the unions at the time of his appointment. The provincial ANC leadership was taken over in September 2009 by P. Masualle, the National Treasurer of the South African Communist Party, a Zuma supporter and then MEC for Health.

At the time of the withdrawal of the Section 100 intervention, unions were waging a campaign to unseat Masualle, with teachers on strike from the start of the school year. The SA Communist Party, also an ANC coalition partner, however, wanted to retain him. ${ }^{2}$ The speculation was that President Zuma withdrew the intervention in order to retain the support of the Eastern Cape ANC leadership and the SACP. ${ }^{3}$ A group of Eastern Cape CSOs filed an application in the Eastern Cape High Court arguing that Presidents Zuma's withdrawal of the intervention was not legal and was trumped by the original agreement between the provincial MEC and the national Education Minister.

In April 2012, however, the head of department's contract ended and was not renewed by the MEC (as was the case for the previous health head of department in 2009), paving the way for more effective national government intervention in the department, still under the original Section 100 memorandum of understanding.

${ }^{1}$ Bongani Nkosi, "NGOs to go to court to force intervention in the Eastern Cape," Mail and Guardian, 2 March 2012.

2 Amukelani Chauke, "Mantashe's Plea to Parents," Sunday Times, 7 February 2012.

${ }^{3}$ Bongani Nkosi, "Motshekga Sigh of Relief After Mannya's Exit," Mail and Guardian, 25 April 2012.

Additional source was an interview with Peires

The difficulty of mounting a successful intervention in the province highlighted by the Education Department case also explains why, in the health program, success was not achieved on more of PSAM's objectives. Box 4 above illustrates the degree to which ANC national and provincial factional politics can cut across efforts to address crucial public resource management shortcomings and service delivery failures.

\section{Conclusion}

PSAM's program of work during the case study period has consistently focused on how critical weaknesses in planning, budgeting and public resource management, and lack of accountability affect health service delivery in the province. By the end of the period, the appointment of a new Superintendent General had begun to address weak accountability in the ECDoH by taking actions against over 1,000 officials — including dismissal and criminal prosecution. This process included high profile cases, such as against the former Superintendent General and chief financial officer. Audit outcomes had improved, while variance and irregular, wasteful, and fruitless expenditure had decreased. The ECDoH, however, still faced critical challenges in resource management.

This paper has argued that the work of PSAM, while not a primary catalyst for the changes observed, has contributed to building the political will necessary for the interventions of the new Superintendent General to succeed. It has also argued that the Eastern Cape presents a difficult environment, in which decisions in the public sphere are not necessarily motivated by service delivery imperative; instead, they are often driven by party politics, especially factional squabbles within the ruling ANC. The degree of change seen, as well as the lack of change in other areas of PSAM focus, should be judged within this context.

PSAM has been able to achieve this impact — despite being a relatively small organization with limited funding — by undertaking high-quality research and analysis work and by using different pathways to advocate for change.

In this regard, the PSAM case study highlights the following lessons for civil society budget work. First, civil society impact on budgets is inseparable from the political context within which it occurs. It is both 
vulnerable to political context, but can also impact on the context themselves. In the Eastern Cape, where politics is not yet truly contestable and political patronage and protection networks are deeply entrenched, PSAM's work had a limited impact. When an important political shift occurred, however, PSAM had an opportunity to improve budgeting and resource management.

Second, an evidence-based advocacy strategy should actively explore different pathways to impact, as shifting circumstances may require agile and flexible action. While the political context did not allow for a broad reform of public resource management in the health sector in the Eastern Cape, PSAM was able to influence it in smaller ways by working directly with the executive. However, if it had used only this pathway and had not at the same time continued with its media work, it collaboration with its strategic partners and its litigation, then it might not have had the same success.

Third, the capacity to utilize multiple pathways was enabled by PSAM's more cooperative strategy during the case study period. It is unlikely that it would have been able to work with the executive if it had continued in its confrontational approach. Furthermore, PSAM's more balanced strategy prevented it from being branded as a lackey of opposition parties, a label which was applied to it at times in its earlier incarnation. Being more cooperative has also enhanced the perception that its research is objective and, therefore, more valued.

Fourth, the ability to progressively influence public policy also faces organizational constraints related to funding. If PSAM had been able to retain its experienced researcher throughout the case study period, or if it had sufficient funds for two researchers to ensure continuity (and if the organizational context was more stable to enable a new researcher to get off the ground more quickly), it would have been well placed to increase its impact by working directly with the department when there was the political will to do so.

PSAM's health program is a good example of how CSOs that are resourced with short-term grants and which are under-resourced compared to the demand for their work often struggle to sustain their accomplishments. 


\title{
Annex 1: Acronyms and Abbreviations
}

\author{
Acronyms and Abbreviations \\ ASSA Actuarial Society of South Africa \\ COSATU Congress of South African Trade Unions \\ CS Statistics South Africa Community Survey \\ CSA Centre for Social Accountability \\ CSO Civil Society Organization \\ ECDoH Eastern Cape Department of Health \\ HIV/AIDS Human immunodeficiency virus/acquired immunodeficiency syndrome \\ IBP International Budget Partnership \\ MDG Millennium Development Goals \\ MEC Member of the Executive Committee (provincial cabinet) \\ PFM Public Financial Management \\ PSAM Public Service Accountability Monitor \\ SADHS South Africa Demographic and Health Survey \\ SAHR South African Health Review \\ StatsSA Statistics South Africa \\ TAC Treatment Action Campaign \\ TB Tuberculosis \\ WHO World Health Organization
}




\section{Annex 2: Bibliography}

\section{Document sources}

Ashley Westaway, "Rural poverty in South Africa: Legacy of apartheid or consequence of contemporary segregationism?" presentation at Conference on Inequality and Structural Poverty in South Africa: Towards Inclusive Growth and Development, Johannesburg, 20-22 September 2010.

Amukelani Chauke, "Mantashe's Plea to Parents," Sunday Times, 7 February 2012.

“A Political Battlefield,” Mail and Guardian, 27 January 2009.

Arden Finn, Jonathan Argent, Murray Leibbrandt, and Ingrid Woolard, "Poverty: Analysis of the NIDS Wave 1 dataset," The Southern Africa Labour and Development Research Unit, University of Cape Town, 2009.

Auditor General of South Africa, "General Report of the National Audit Outcomes of the Eastern Cape, Fiscal Year 2007/8,” Pretoria, 2008.

Auditor General of South Africa, "Consolidated Audit Findings for the Eastern Cape Province 2010/11," Pretoria, 2011.

Auditor General of South Africa, "General Report of the National Audit Outcomes of the Eastern Cape, Fiscal Year 2009/10," Pretoria, 2011.

Bongani Nkosi, "NGOs to go to court to force intervention in the Eastern Cape," Mail and Guardian, 2 March 2012.

Bongani Nkosi, "Motshekga Sigh of Relief After Mannya's Exit," Mail and Guardian, 25 April 2012.

Bruce Weber, "Manto Tshabalala-Msimang, South African Who Oversaw Discredited AIDS Policy, Dies at 69," The New York Times, 16 December 2009.

Candy Day and Andy Gray, "Health and Related Indicators" in South African Health Review 2008, ed. Peter Barron and Josianne Roma-Rearden, (Durban: Health Systems Trust, 2008), pp. 239-396.

Chris Barron, "So Many Questions," The Sunday Times, 8 July 2012.

Chris Bateman, "Corruption Busting: A Real Health Threat," South African Medical Journal, (June 2011), pp. 360-362.

Chris Bateman, "Pre-NHI Cleanup: Motsoaledi Enlists Private Sector," South African Medical Journal, (July 2011), pp. 438-442.

"Corruption Costs Eastern Cape R35 million," Eastern Cape Herald, 2011.

Debbie Bradshaw, Pam Groenewald, Jané Joubert, Ria Laubscher, Nadine Nannan, Beatrice Nojilana, Rosana Norman, Desiréé Pieterse, and Michelle Schneider, "South African National Burden of Disease Study 2000 Eastern Cape Province," Burden of Disease, Research Unit Medical Research Council, Cape Town, n.d.

Daygan Eagar, "Budget Analysis, Eastern Cape Department of Health, 2008/9," Centre for Social Accountability, Grahamstown, 2008. 
Daygan Eagar, "Expenditure Tracking Report, Eastern Cape Department of Health, 2007/8," Centre for Social Accountability, Grahamstown, 2008.

Daygan Eagar, "Strategic Plan Evaluation, Eastern Cape Department of Health, 2008/9," Centre for Social Accountability," Grahamstown, 2008.

Daygan Eagar, "Financial Crisis in the Eastern Cape Health Department," Section27, Johannesburg, 2012.

Eastern Cape Department of Health, "Annual Performance Plan," Bhisho, Eastern Cape Department of Health, 2009.

Eastern Cape Department of Health, "Annual Performance Plan," Bhisho, Eastern Cape Department of Health, 2012.

Eastern Cape Department of Health, "Annual Report 2009/10," Bhisho, Eastern Cape Department of Health, 2010.

Eastern Cape Department of Health, "Denosa Condemms Medicine Theft," Bhisho, Eastern Cape Department of Health, 2010.

Eastern Cape Department of Health, "Strategic Plan 2009/10 to 2013/14," Bhisho, Eastern Cape Department of Health, 2010.

"Five Senior Government Officials Nabbed in Eastern Cape Fraud Blitz," Mail and Guardian, 27 February 2012.

G. Zine, "Health Sacks Finance Boss," Dispatch Online, East London., 2011.

Health Systems Trust, "Eastern Cape - Health Care Crisis," Health Systems Trust Bulletin, 2003.

Human Sciences Research Council, "Service need and provision in the Eastern Cape," Pretoria, Human Sciences Research Council, 1998.

Jay Kruuse and Derek Luyt, "Taking the Auditor General More Seriously," Centre for Social Accountability, Grahamstown, 2007.

Karl Von Holdt, "Can a weak state be a developmental state? Questions arising from institutional weaknesses in the South African state," presentation at Conference on The Potentials for and Challenges of Constructing a Democratic Developmental State in South Africa, Magaliesberg, Magaliesberg, South Africa, 4 June 2008.

Kate Lefko-Everett "2012 SA Reconciliation Barometer Survey Report," Institute for Justice and Reconciliation, Cape Town, 2012.

National Department of Health,"Statement on National Health Insurance at the Health Leaders Retreat 2010," 2010, available at http://www.doh.gov.za/show.php?id=2116.

P. Jaffray and L. Miti, "Primary Health Care Service Delivery," The Eastern Cape Basic Services Delivery and Socio Economic Trends Series, No 7, Fort Hare Institute of Social and Economic Research, University of Fort Hare, 2010. 
Peter Barron, Reginald Broekman, et al., "Eastern Cape Department of Health: Report of the Integrated Support Team," Report commissioned by the National Minister of Health, Barbara Hogan, 2010, available at http://section27.org.za.dedi47.cpt1.host-h.net/wp-content/uploads/2010/09/Eastern-Cape.pdf.

Peter Barron, Hanno Gouws, Bertie Loots, Gitesh Mistry, Laetitia Rispel, Annie Snyman, and Konrad van Nieuwenhuizen, "Consolidated Report of the Integrated Support Team," Report commissioned by the Minister of Health, Barbara Hogan, 2010.

Peter Barron, Hoosen Coovadia, Rachel Jewkes, Diane McIntyre, and David Sanders,"Health in South Africa: The Health and Health System of South Africa: Historical Roots of Current Public Health Challenges." The Lancet (September 2009), pp. 817-834.

Public Service Commission, "Report on Senior Management Service Compliance with Performance Agreements in the Eastern Cape Provincial Administration," Pretoria, 2007.

Sharon Stone, "The 2009 TIME 100: Barbara Hogan," Time Magazine, 30 April 2009.

Sizathu Tosca Cwati, "Comparing Anti-corruption strategies in South Africa's Western and Eastern Cape Provinces," Research Report submitted in partial fulfillment of the requirements for the degree of Master of Public Administration, University of the Western Cape, Cape Town, 2004.

StatsSA, "Measuring Poverty in South Africa," Statistics South Africa, Pretoria, 2002.

Thokozile Mtsolongo, "Eastern Cape Department of Health, Budget Analysis, 2012/13," Public Service Accountability Monitor, Grahamstown, 2012.

Times LIVE, "ANC elite hoodwinking the poor - Moeletsi Mbeki," 5 May 2012, http://www.timeslive.co.za/politics/2012/05/25/anc-elite-hoodwinking-poor---moeletsimbeki.

Vuyisile Msila, "Teacher unionism and School Management: a Study of Eastern Cape Schools in South Africa," Education Management, Administration and Leadership, 2012. 


\section{List of Interviews (2010, 2011, 2012)}

$\begin{array}{ll}\text { Allen, C } & \text { Former Head PSAM } \\ \text { Barkhuizen, D } & \text { Daily Dispatch news editor } \\ \text { Dimaza, M } & \text { Chair of Health Committee, Provincial Legislature } \\ \text { Eager, D. } & \text { Researcher Health, PSAM, now with Section 27 } \\ \text { Frachet, S. } & \text { Eastern Cape Department of Health } \\ \text { Hayward, B. } & \text { Health Reporter, The Herald, a provincial daily newspaper } \\ \text { Henriks, A. } & \text { Health Reporter, Die Burger, a national daily newspaper } \\ \text { Komisa, M. } & \text { SABC, national television broadcaster. } \\ \text { Kota, Z } & \text { Education Researcher, PSAM } \\ \text { Kruuse, J. } & \text { Head of Monitoring and Advocacy Team, PSAM } \\ \text { Luyt, D. } & \text { Head of Communication Program, PSAM } \\ \text { Majavu, A. } & \text { The Sowetan, national daily newspaper } \\ \text { Malamlela, X. } & \text { Provincial Secretary, Nehawu - a national trade union in the health sector. } \\ \text { Matomela, M } & \text { Chair of Finance Committee, Provincial Legislature } \\ \text { Mtsolongo, T } & \text { PSAM health researcher (from mid-2011) } \\ \text { Mugizi, G } & \text { PSAM Staff, Acting Director } \\ \text { Muthwa, S } & \text { Deputy Director General, Office of the Premier } \\ \text { Overy, N } & \text { Independent researcher and consultant, former employee of PSAM. } \\ & \text { Former Head of Department, Economic Services and Environmental Affairs } \\ \text { Peires, J (Prof) } & \text { Eastern Cape, retired academic Rhodes University of Rhodes } \\ \text { Rayi, M. } & \text { Cosatu, a national trade union federation Eastern Cape } \\ \text { Seaworyeh, J } & \text { Head of Budget Office, Eastern Cape Treasury } \\ \text { Sephthon, S } & \text { Legal Resources Centre, a national CSO with a branch in the Eastern Cape } \\ \text { Tshoko, L. } & \text { Strategic Planning Unit, Eastern Cape Department of Health } \\ \text { Vitshima, V. } & \text { ScopaStanding Committee on Public Account, Provincial Legislature } \\ \text { Walton, J. } & \text { Black Sash, a national CSO, and former ANC Councillor }\end{array}$




\section{Annex 3: Selected health indicators for the Eastern Cape 2007-08}

Health outcomes confirm the Eastern Cape's relative socioeconomic status compared to other provinces. In a 2008 overview of the status of South Africa with regard to health MDG indicators, the Eastern Cape rated last of the nine provinces with regard to five key indicators as set out in Table 1.1.

Table 1.1 Selected Millennium Development Goal indicators: Eastern Cape versus the best performing province

\begin{tabular}{lcccc}
\hline \multicolumn{1}{c}{ Indicator } & Definition & Eastern Cape & $\begin{array}{c}\text { Western Cape } \\
\text { unless stated }\end{array}$ & Year and source \\
\hline Under-5 mortality & deaths per 1,000 live births & 81 & 39 & 1998 SADHS \\
Infant Mortality & deaths per 1,000 live births & 59 & 24 & $\begin{array}{l}2008 \text { ASSA } \\
\text { Projection }\end{array}$ \\
$\begin{array}{l}\text { Delivery rate in a facility } \\
\text { \% of births in facility }\end{array}$ & $65 \%$ & $92.40 \%$ & 2006 DHIS \\
$\begin{array}{l}\text { \% of households with access to } \\
\text { piped water } \\
\% \text { of households with no toilet }\end{array}$ & $\%$ of households & $70.80 \%$ & $99 \%$ & 2007 StatsSA CS \\
\hline Source: Day and Gray (2008) & $\%$ of households & $23.50 \%$ & $3.2 \%$ (Free State) & 2008 StatsSA CS \\
\hline
\end{tabular}

In terms of health service delivery, the Eastern Cape had the lowest ranking for facility deliveries (65.3 percemt against the South African average of 80.6 percent). Its performance was third from the bottom in terms of TB cure rate (59.6 percent), immunization coverage (78.9 percent) and immunization dropout (4.8 percent). In two of the indicators however, performance was above average (PHC utilization rate and proportion of ANC clients tested for HIV) and also for male condom distribution it was ranked 4th rather than among the bottom 4 .

Table 1.2 Eastern Cape health service delivery indicators in comparative perspective

\begin{tabular}{|c|c|c|c|c|c|c|c|}
\hline Province & $\begin{array}{c}\text { PHC } \\
\text { utilisation } \\
\text { rate }\end{array}$ & $\begin{array}{l}\text { TB cure } \\
\text { rate }\end{array}$ & $\begin{array}{c}\text { Male } \\
\text { condom } \\
\text { distribution } \\
\text { rate }\end{array}$ & $\begin{array}{l}\text { Proportion of } \\
\text { ANC clients } \\
\text { tested for HIV }\end{array}$ & $\begin{array}{c}\text { Immunisation } \\
\text { coverage rate } \\
\text { (\%) }\end{array}$ & $\begin{array}{l}\text { Immunisation } \\
\text { drop-out }\end{array}$ & $\begin{array}{c}\text { Facility } \\
\text { delivery rate }\end{array}$ \\
\hline & $2007 / 08$ & $2007 / 08$ & $2007 / 08$ & $2007 / 08$ & $2007 / 08$ & $2006 / 07$ & 2007 \\
\hline Eastern Cape & 2.4 & 59.6 & 9.3 & 88.3 & 78.9 & 4.8 & 65.3 \\
\hline Free State & 2.0 & 69.1 & 6.7 & 80.1 & 86.6 & 2.6 & 84.8 \\
\hline Gauteng & 1.7 & 71.1 & 7.1 & 73.3 & 91.6 & 0.7 & 84.3 \\
\hline KwaZulu Natal & 2.2 & 52.9 & 7.4 & 70.7 & 82.1 & 4.9 & 78.1 \\
\hline Limpopo & 2.6 & 60.4 & 12.9 & 90.1 & 78.6 & 2.6 & 86.8 \\
\hline Mpumalanga & 2.0 & 56.1 & 10.6 & 74.6 & 78.5 & 1.0 & 81.4 \\
\hline Nothern Cape & 2.9 & 69.1 & 5.4 & 88.5 & 82.6 & 3.6 & 80.4 \\
\hline North West Province & 2.5 & 59.7 & 6.4 & 85.6 & 77.9 & 4.1 & 75.9 \\
\hline Western Cape & 2.7 & 77.3 & 40.5 & 95.7 & 100.5 & 6.5 & 87.2 \\
\hline South Africa & 2.2 & 62.7 & 11.8 & 79.6 & 84.2 & 3.4 & 80.6 \\
\hline
\end{tabular}

In terms of primary health care spending per capita, the Eastern Cape also ranked in the bottom half in 200708, with only the Free State and Limpopo performing worse. While it has one of the highest number of medical practitioners and nurses in the public sector, in terms of staff per 100, 000 uninsured population, its performance against puts it in the bottom half. 
Table 1.3 Eastern Cape health service delivery inputs in comparative perspective

\begin{tabular}{lrrrrr}
\hline \multicolumn{1}{c}{ Province } & $\begin{array}{c}\text { Per capita } \\
\text { primary } \\
\text { health care } \\
\text { expenditure }\end{array}$ & $\begin{array}{c}\text { Number of } \\
\text { nursing } \\
\text { staff in } \\
\text { public } \\
\text { sector }\end{array}$ & $\begin{array}{c}\text { Public } \\
\text { sector } \\
\text { nursing } \\
\text { staff per } \\
\mathbf{1 0 0 , 0 0 0} \\
\text { uninsured } \\
\text { population }\end{array}$ & $\begin{array}{c}\text { Number of } \\
\text { medical } \\
\text { practitioners } \\
\text { in public } \\
\text { sector }\end{array}$ & $\begin{array}{c}\text { Public sector } \\
\text { medical } \\
\text { practitioners } \\
\text { per 100,000 } \\
\text { uninsured } \\
\text { population }\end{array}$ \\
\hline & $2007 / 08$ & $2007 / 08$ & $2007 / 08$ & $2007 / 08$ & $2007 / 08$ \\
\hline Eastern Cape & 265 & 13,761 & 203.5 & 1,157 & 17.9 \\
Free State & 233 & 4925 & 187.2 & 609 & 23.2 \\
Gauteng & 312 & 16975 & 247.4 & 2,196 & 32 \\
KwaZulu Natal & 312 & 20856 & 237.4 & 3,044 & 34.7 \\
Limpopo & 271 & 12097 & 238.4 & 883 & 17.4 \\
Mpumalanga & 237 & 5898 & 190.6 & 567 & 18.3 \\
Nothern Cape & 341 & 1992 & 259.1 & 275 & 35.7 \\
North West Province & 340 & 6487 & 183.8 & 498 & 14.1 \\
Western Cape & 428 & 8632 & 230.8 & 1,418 & 37.9 \\
\hline South Africa & 302 & 91,623 & 223.4 & 10,653 & 26 \\
\hline Sources: Day, Baron et al. (Health Systems Trust) 2009 (Database Appendix); Day and Gray 2008.
\end{tabular}

Sources: Day, Baron et al. (Health Systems Trust) 2009 (Database Appendix); Day and Gray 2008. 